CCA 5273

\title{
CHEMICAL INTERFERENCE BY DRUGS AND OTHER SUBSTANCES WITH CLINICAL LABORATORY TEST PROCEDURES
}

WENDELL T. CARAWAY AND CARL W. KAMMEYER

McLaren Geneval Hospital, St. Joseph Hospital, The Flint Medical Labovatory, and The University of Michigan-Flint, Flint, Mich. 48502 (U.S.A.)

(Received June $\mathrm{r}$, I972)

\section{SUMMARY}

A critical review of the original literature has been made to identify drugs and other substances which interfere chemically with clinical laboratory test procedures. The nature and extent of such interference has been correlated with particular methuds of analysis.

Medications may alter laboratory test values through a variety of pharmacological, physical or chemical mechanisms. Pharmacologically, a drug may cause a true change in the concentration of the particular substance being measured. Thus, allopurinol, a xanthine oxidase inhibitor, is used to reduce plasma uric acid levels in selected patients. Incidental pharmacologic effects, other than those primarily intended, may also occur. Antiovulatory drugs, uscd for contraccptive purposes, causc an increase in total serum thyroxine-binding globulin. This results in an increase in both total serum thyroxine and unsaturated thyroxine-binding globulin, but no significant change in unbound ("free") thyroxine. Recognition of these effects is essential in the interpretation of thyroid function tests. Drugs may also cause undesirable toxic or side effects, as evidenced by changes in liver or renal function tests. Thus, in some individuals, phenothiazines will produce a picture of obstructive jaundice, with elevation in serum bilirubin and alkaline phosphatase. Knowledge of the pharmacologic effects of drugs helps to explain a number of correct but otherwise unexpected laboratory results. Several reviews, dealing primarily with such changes, have appeared recently ${ }^{1-3}$.

Chemically, a drug or its metabolite may interfere with the accurate determination of the desired constituent. For example, methyldopa, used in the treatment of hypertension, will produce a false positive result for urinary catecholamines, since it reacts in the method to produce a green fluorescence similar to that produced by norepinephrine. This could lead to an erroneous diagnosis of pheochromocytoma. Radiographic contrast media, containing iodinated organic compounds, invalidate protein-bound iodine determinations because of their own high iodine content. Other 
drugs can interfere by producing extraneous color reactions, by chelation, or by inbibition of enzyme activity.

In addition to chemical interferences by drugs, one should also consider the effects of anticoagulants and of marked changes in concentrations of normally occurring substances in body fluids which alter la.boratory test values. Hemolysis, lipemia, and elevated serum bilirubin interfere in a number of procedures. In uremia, associated high levels of creatinine and uric acid can result in falsely elevated values for glucose as measured by alkaline ferricyanide methods.

Chemical interferences arise primarily from lack of specificity of the methods used to measure desired constituents. The usual methods of quality control, such as including a control serum or standard with each series of determinations, will not detect errors arising from some interfering substance in one of the unknowns. This problem of specificity is an area of special concern to the clinical chemist.

In I968, Elking and Kabat ${ }^{4}$ tabulated over $\mathbf{I}_{500}$ citations relevant to druginduced modifications of laboratory test values. Garb ${ }^{5}$, in a recent book, includes this and additional information in handy tabular form. Martin ${ }^{6}$, in his text, also includes tables on drug interference with clinical laboratory tests. These valuable contributions list the effects of drugs as resulting either in an elevated (or false positive) value or a decreased (or false negative) value but do not distinguish, for the most part, between pharmacologic effects and chemical interferences. An exception is the work of Hansten?, who presents discussions concerning the effects of drugs on clinical laboratory test values and distinguishes those in which the effect is due to interference with the testing procedure.

Another problem is to determine whether a reported drug interference was observed at realistic concentrations which are likely to occur in serum or urine during a typical therapeutic regimen. We have found, for example, that methyldopa, in concentrations of Io $\mathrm{mg} / \mathrm{dl}$, will cause spurious elevations of results obtained in the determination of uric acid. The usual dosage schedule for methyldopa, however, leads to plasma concentrations of approximately $0.2 \mathrm{mg} / \mathrm{dl}$ and urine concentrations of approximately $10-25 \mathrm{mg} / \mathrm{dl}^{8}$. At these levels, interference with determinations on urine is substantial but for serum it is insignificant.

Several approaches have been used to investigate the effects of drugs on laboratory test values. Naumann ${ }^{9}$ studied the effect of a single drug, phenazopyridine (Pyridium), on a number of procedures. O'Kell et al. ${ }^{10}$ added antibiotics to serum to approximate levels likely to be encountered in patients and found no interference in I2 automated methods of analysis. Singh et al. ${ }^{11}$, analyzed solutions of 45 medications, at I mmole/liter concentrations, on the Technicon SMA r2/60 and found significant interference from 25. Of these, 8 showed significant interference at concentrations likely to occur in plasma after a single maximum therapeutic dose. With a screening battery of 9 tests, Van Peenen and Files ${ }^{12}$ found negligible differences in test results from a series of 2500 patients either receiving or not receiving 12 commonly administered medications. These findings, of course, apply only to the test procedures and medications studied. Cryer and Sode ${ }^{13}$ investigated a number of analgesics and tranquilizer-sedatives to determine those which could be uscd during diagnostic cvaluation of adrenal function without pharmacologic or chemical alteration of urinary hormonal values. Borushek and Gold ${ }^{14}$, in a classic study, determined the effects of 23 drugs on values for urinary $I 7$-ketosteroids and I 7 -hydroxycorticosteroids. These drugs were 
tested in pure solution and in combination with pure standards. In addition, they were administered to patients to determine the change in test values on 24-hour urine collections. All of these various approaches have merit and could be expanded to include more medications and different methods of analysis.

In the present study, a critical review of the original literature has been made with respect to chemical interferences in clinical laboratory test procedures. Attention has been directed especially to the methods employed and, where possible, to the nature and extent of such interferences. Ready availability of this information should help to explain certain anomalous test results and stimulate development or adoption of more specific methods of analysis.

\section{TABULATIONS}

The information is arranged alphabetically according to test procedures. Subheadings, describing the analytical method affected, are followed by alphabetical listings of interfering substances. The latter are preceded by the notation $(+)$ or $(-)$ to indicate that the substance causes a false increase or false decrease, respectively, in test values. A substance reported to show no interference with the test is preceded by the notation $(\mathrm{O})$. References are given to the original literature, but no claim is made for complete coverage. Some selection in choice of citations has been exercised, when multiple observations in substantial agreement have been reported. In some cases, we have augmented the material with personal observations or experiments and these have been so indicated.

Interferences from bilirubin, hemoglobin, lipemic serum, color of urine, etc., cause obvious problems with various spectrophotometric or visual examinations. Chemical interferences from these sources have not been listed, unless special circumstances seemed to warrant them. Interferences from impurities in reagents or distilled water have not been included, with a few exceptions, inasmuch as these can normally be detected or corrected by inclusion of reagent blanks, standards, and recovery experiments.

Drugs are listed by generic name, followed, in some cases, by the more common brand name or names. This information has been taken from Facts and Comparisons ${ }^{15}$, updated to I972. This publication is very convenient for such cross-referencing.

AMYLASE

The following anticoagulants are reported to reduce plasma amylase activity about $20 \%$ as compared to serum or heparinized plasma.

(-) Citrate ${ }^{16}$

(-) Fluoride ${ }^{17}$

(-) Oxalate ${ }^{16,17}$

\section{BARBITURATES}

A. Screening tests on serum or urine depend upon the formation of mercuric salts which are soluble in chloroform. Addition of dithizone (diphenylthiocarbazone) results in a change of color from blue to orange if barbiturates are present ${ }^{18}$. With diphenyl- 
carbazone, the color change is from red to deep purple ${ }^{19}$. Our own observations are based on the latter procedure.

$(+)$ Chlordiazepoxide (Librium). We have observed false positives with toxic overdoses only.

(+) Chlorpheniramine ${ }^{18}$. Interferes only at toxic levels (over $4 \mathrm{mg} / \mathrm{dl}$ ).

$(+)$ Diazepam (Valium). We have observed false positives with toxic overdoses only.

(t) Diphenylhydantoin ${ }^{18}$. Reported to give a positive reaction at a concentration of $8 \mathrm{mg} / \mathrm{dl}$.

(十) Glutethimide (Doriden) ${ }^{18}$. Reported to give a positive reaction at a concentration of $5 \mathrm{mg} / \mathrm{dl}$.

(+) Meperidine (Demerol). We have observed false positives in patients receiving the drug and in vitro at concentrations of $\mathrm{ro} \mathrm{mg} / \mathrm{dl}$.

(+) Methyprylon ${ }^{18}$. Interferes only at toxic levels (over $55^{\circ} \mathrm{mg} / \mathrm{dl}$ ).

$(+)$ Tin. May be present in filter paper ${ }^{20}$. Reacts with diphenylcarbazone to produce a deep purple color.

(+) Tolbutamide. We have observed false positives in patients receiving the drug and in vitro at concentrations of $\mathrm{Io} \mathrm{mg} / \mathrm{dl}$.

$B$. Ultraviolet spectrophotometric methods based on absorbance readings at $239 \mathrm{~nm}$ at $\mathrm{pH}$ Io and on decrease in absorbance after acidification.

(-) Salicylate. Extracted with barbiturates and shows an increase in absorbance after acidification. Suitable corrections can be made ${ }^{21}$.

BILIRUBIN

A. Sermm bilimbin is determined by reacting it with diazotized sulfanilic acid to produce reddish-violet azobilirubin. In the Malloy-Evelyn method, the final mixture is acid and contains $50 \%$ methanol. A serum blank is included routinely.

$(+)$ Dextran ${ }^{22}$. Used as a plasma expander and produces turbidity in presence of methanol. Serum blanks tend to be variable and do not provide adequate correction.

(-) Hemoglobin ${ }^{23}$. Nitrite converts hemoglobin to methemoglobin. Decreased values for bilirubin may be related to competition for nitrite between hemoglobin and sulfanilic acid.

B. Direct spectrophotometric estimation of bilirubin. Readings are made at 2 wavelengths to correct for absorbance by hemoglobin. Single readings at one wavelength (usually $460 \mathrm{~nm}$ ) are reported in terms of "icterus index".

$(+)$ Carotene. This pigment is normally present in serum and appears in excess after ingestion of large amounts of carrots or other yellow-colored vegetables.

$(+)$ Hemoglobin. Causes spurious elevation in icterus index, especially if readings are made at $420 \mathrm{~nm}$ rather than $460 \mathrm{~nm}^{24}$.

(+) Lipemia. Contributes to absorbance and is not corrected by reading at 2 wavelengths since the apparent absorbance of turbid solutions increases as wavelength is decreased.

(+) Novobiocin. A yellow lipochrome metabolite of the drug appears in plasma ${ }^{25}$. C. Bilirubin in urine is detected by reaction with an acidified diazonium compound, available in tablet or test strip form, to produce a blue to purple color (e.g., Ictotest, Ames Co.).

Clin. Chim. Acta, 4工 (1972) 395-434 
$(+)$ Ethoxazene (Serenium). Colors the urine orange-red and may be misinterpreted as positive for bilirubin.

$(+)$ Phenazopyridine (Pyridium). Colors the urine orange-brown and becomes reddish-brown in acid solution. May be misinterpreted as positive for bilirubin ${ }^{9}$.

BLOOD, OCCULT

This determination is done on urine or feces to detect amounts of blood not grossly visible. Hemoglobin, myoglobin, and hematin exhibit peroxidase-like activity which, in the presence of hydrogen peroxide effects oxidation of various substrates such as guaiac, benzidine, and o-tolidine to produce color. Peroxidases from other sources may be removed by boiling the specimen. Various tablets and reagent strips have been formulated to improve stability of the reagents. Sensitivity, effects of diet, and iron salt therapy have been reviewed ${ }^{26}$.

(-) Ascorbic acid. Competes with chromogen. Levels in urine exceeding $50 \mathrm{mg} / \mathrm{dl}$ inhibit the reaction.

(+) Bacteria. Old urine specimens may show peroxidase activity associated with excess growth of certain bacteria.

$(+)$ Bromide. Reacts in vitro but is unlikely to be present in urine or feces in quantities sufficient to produce false positives ${ }^{27}$.

$(+)$ Iodide. Same reaction as bromide ${ }^{27}$.

(+) Iron salts. Feces are colored black. May show false positive with guaiac test if tannic acid is present as a contaminant in the reagent ${ }^{27}$.

(+) Methyldopa. Patients receiving this drug do not show a color change in the urine. Specimens collected in containers cleancd with bleach (hypochlorite) may turn reddish-brown immediately, giving a false impression of blood in the urine ${ }^{2 s}$.

(+) Sulfobromophthalein (BSP). Alkaline stools may appear "bloody" but tests for occult blood are negative ${ }^{y 9}$.

(-) Tetracyclines. Some preparations contain high concentrations of ascorbic acid as preservative. Large amounts in the urine inhibit color development.

BSP TEST

Sulfobromophthalein (BSP) is injected intravenously, usually in doses of 5 $\mathrm{mg} / \mathrm{kg}$ of body weight, as a test of liver function. Blood is drawn after $45 \mathrm{~min}$, and the serum made alkaline to develop the color of the remaining BSP. Increased values are observed in liver disease, due to failure of conjugation or excretion by the liver.

(+) Anabolic steroids (e.g., norethandrolone). These appear to affect liver function as evidenced by concurrent increase in serum lactic dehydrogenase or bilirubin ${ }^{30,31}$.

(+) Topanoic acid (Telepaque). This and other radiographic contrast media compete with BSP for excretion by the liver ${ }^{30,32,33}$. The two tests should not be performed at the same time.

(-) Phenazopyridine (Pyridium). Methods in which acidified serum blanks are used produce low results since the drug produces a pink color in acid solution. A preinjection alkalinized serum blank is recommended".

(+) Phenolsulfonphthalein (PSP). Used as a test of kidney function and produces similar color in alkaline solution; hence, the two tests should not be performed at the same time. 
CALCIUM

Methods for determining calcium in biologic materials have been reviewed recently by Martinek ${ }^{34}$.

A. Enission spectrophotometry (flame photometry). This method of analysis has not gained much favor in the clinical laboratory, owing to relatively low concentrations of calcium in serum, high temperature flame requirements, and interference by various substances.

(+) Sodium ${ }^{35,36}$. Enhances the calcium signal. Excess sodium is added to both standards and unknowns to minimize effect.

(-) Phosphate ${ }^{35,37,38}$. The depressant effect can be minimized by adding phosphate to standards.

B. Atomic absorption spectrophotometry. The following substances are reported to depress observed values for serum calcium, but the effect can be counteracted (except for protein) by adding lanthanum chloride to standards and unknowns ${ }^{39}$.

(-) Edetate (EDTA).

(-) Oxalate.

(-) Phosphate.

(-) Protcin. Compcnsatc by adding protcin to standards.

(-) Sulfate.

C. Precipitation of calcium with oxalate. The precipitate is washed to remove excess oxalate, dissolved in acid, and titrated with potassium permanganate under controlled conditions.

(-) Edetate (EDTA). May be present in serum from patients treated with EDTA. The serum should be acidified to $\mathrm{pH} 3^{-5}$ before precipitating calcium with oxalate ${ }^{40}$.

(O) Magnesium. No magnesium oxalate is precipitated provided the $\mathrm{pH}$ is less than $7.0^{41}$.

D. Methods dependent upon titration of calcium ions with EDTA, using various colorimetric or fluorometric endpoints, or upon direct spectrophotometric determinations based on production of color with suitable calcium indicators in alkaline solution. A wide choice of indicators and final working conditions have been used. Actual degree of interference from the following substances must be determined for the particular method employed.

(士) Bilirubin. May interfere with endpoint detection in titrimetric methods. Contributes to absorbance in photometric methods.

(-) Citrate $^{42}$. Chelates calcium ions. May be present in serum following transfusions of citrated blood.

(+) Copper (II). Unlikely to be present in significant concentrations in biological fluids. Addition of cyanide overcomes interference ${ }^{43,44}$.

(-) Edetate (EDTA). Chelates calcium ions. May be present in serum from patients treated with EDTA.

$(+)$ Iron (II). Unlikely to be present in significant concentrations in biological fluids. Addition of cyanide overcomes interference ${ }^{\mathrm{a}, a 4}$.

(+) Magnesium. Interference depends on specificity of the indicator for calcium and on $\mathrm{pH}$ of final reaction mixture.

(-) Phosphate. Complexes calcium ions. Extent of interference depends on relative

Clin. Chim. Acta, 41 (1972) 395-434 
and absolute concentrations of calcium and phosphate ions. Interference is more common in determinations on urine owing the high phosphate levels. All methods must be evaluated individually ${ }^{42,45}$.

$(+)$ Sulfobromophthalein (BSP). Produces a violet color in alkaline solution which contributes to absorbance or obscures endpoint in titrimetric methods.

$(+)$ Zinc. Unlikely to be present in significant concentrations in biological fluids. Addition of cyanide overcomes interference ${ }^{\mathbf{4 3 , 4 4}}$.

\section{CATECHOLAMINES}

A. In the screening method of Hingerty ${ }^{46}$, epinephrine and norepinephrine in urine are adsorbed on aluminum oxide at $\mathrm{pH} 8.4$, eluted with dilute acid and oxidized with ferricyanide at $\mathrm{pH} 6.5$. Addition of strongly alkaline ascorbate effects ring closure with formation of adrenochromes which produce a green fluorescence. In quantitative procedures, internal standards and sample blanks are included ${ }^{47}$.

$(+)$ B-complex vitamins ${ }^{1}$. Large doses, especially of riboflavin, can produce similar fluorescence.

(+) Erythromycin ${ }^{48}$. Produces fluorescence in Hingerty's method.

(-) Formaldehyde ${ }^{49}$. Inhibits fluorescence of added recovery standard in methods based on condensation of catecholamines with ethylenediamine.

(+) Isoproterenol ${ }^{50}$. Inhaled as a bronchodilator. Metabolite produces false positives.

(t) Levodopa ${ }^{50}$. Produces fluorescence similar to norepinephrine.

(-) Methenamine mandelate (Mandelamine) ${ }^{49}$. This and other drugs containing methenamine release formaldelıyde which inhibits fluorescence (see above).

(+) Methyldopa ${ }^{51}$. This drug, itself a catecholamine, is the most common cause of false positive tests for catecholamines.

$(+)$ Quinidine, quinine ${ }^{52}$. Metabolites produce fluorescence.

$(+)$ Salicylates ${ }^{1}$. Produce interfering fluorescence.

(+) Tetracyclines ${ }^{48}$. Produce interfering fluorescence. Crout ${ }^{47}$ lists a number of drugs which do not affect urinary catecholamine determinations by his procedure.

B. Metanephrines (methoxycatecholamines) are determined according to Pisano $^{53}$ by acid hydrolysis, adsorption on $\Lambda$ mberlite resin, elution, conversion to vanillin with periodate, and measurement at $360 \mathrm{~nm}$.

$(+)$ Chlorpromazine ${ }^{54}$. The drug and its metabolites cause a false elevation.

$(+)$ Imipramine ${ }^{54}$. Preliminary observations suggest interference.

(-) Methylglucamine ${ }^{55}$. Present in certain radiopaque dyes (Renovist, Renografin) and consumes periodate, preventing oxidation of metanephrines to vanillin.

\section{CHLORIDE}

A. Titration with mercuric nitrate to form nonionized mercuric chloride. Diphenylcarbazone indicator is used to detect the endpoint.

$B$. Coulometric-amperometric titration by generation of silver ions.

(+) Bromide. This ion reacts similarly to chloride in the above methods. In bromide poisoning, however, the bromide tends to replace chloride and the sum of the two halogens gives an apparent normal value for chloride ${ }^{56}$.

C. Methods based on halide displacement of mercury from mercuric thiocyanate 
with resultant formation of ferric thiocyanate. Absorbance measurements are made on the red-colored complex at $480 \mathrm{~nm}$ (manual or automated methods).

$(+)$ Bromide. Equimolar quantities of bromide yield more ferric thiocyanate in the reaction than does chloride. Thus, in the presence of bromide, this method yields higher results than the preceding methods ${ }^{56,57}$.

\section{CHOLESTEROL}

Cholesterol methodology has been reviewed recently by Tonks ${ }^{58}$ and Martinek ${ }^{50}$. A. Methods based on the Liebermann-Burchard reaction (acetic anhydride-sulfuric acid) applied directly to serum ${ }^{60}$. A green color is produced.

(+) Bilirubin. Converted to green pigment, biliverdin, in the reaction mixture. One $\mathrm{mg}$ of bilirubin is reported to produce color equivalent to as much as $20 \mathrm{mg}$ of cholesterol ${ }^{61}$. Interference is less in procedures involving preliminary extraction. The method of Abell et al. ${ }^{62}$, is generally recognized as a highly specific and satisfactory standard method for cholesterol determinations.

$B$. Methods based on reaction with ferric ion in acetic acid-sulfuric acid mixture. $A$ violet color is produced. The reaction may be applied directly to serum, as described by Zlatkis et $a l .{ }^{63}$, or to protein-free extracts ${ }^{64}$.

$(+)$ Aminopyrine (Pyramidon). Interference has been reported ${ }^{58}$.

$(+)$ Bilirubin. Interference is less when protein precipitation or solvent extraction is used $^{65}$. Various approaches have been used to eliminate bilirubin ${ }^{69}$.

$(+)$ Bromide. Reportedly interferes when isopropanol extracts are used but not with ethanol extracts ${ }^{66}$. With isopropanol extracts, a serum bromide level of Io mmole/ liter increased the apparent serum cholesterol by $30 \mathrm{mg} / \mathrm{dl}$. Preliminary precipitation of bromide with silver ion has been suggested ${ }^{67}$.

$(+)$ Chlorpromazine. Fifty $\mu \mathrm{g}$ in the final reaction mixture produced a red color with absorbance of $0.23^{68}$. No interference was encountered in a proposed fluorometric method.

(-) Nitrates and nitrites. These inhibit color development and the effect is the same per mole. Rice ${ }^{6 \theta}$ has shown that Io $\mu \mathrm{g}$ of nitrate or nitrite in the final reaction mixture reduced the apparent cholesterol level by approximately $30 \%$. Nitrate may be present in sulfuric acid. We have encountered nitrite in one lot of isopropanol sufficient to depress the absorbance on a $200 \mathrm{mg} / \mathrm{dl}$ standard by $25 \%$.

$(+)$ Salicylates. Interference has been suggested ${ }^{58}$. We have added salicylate to serum to produce levels of Ioo $\mathrm{mg} / \mathrm{dl}$ and have found no interference when the iron reaction is applied to isopropanol extracts.

(-) Thiouracil. When used as a preservative at levels of $\mathrm{I} 3 \mathrm{mg} / \mathrm{dl}$, the apparent serum cholesterol was decreased by $30-40 \mathrm{mg} / \mathrm{dl}^{70}$.

$(+)$ Tryptophan. Present in protein and produces a red color in the direct reaction when glyoxylic acid is present as a contaminant in acetic acid ${ }^{71}$. Henry ${ }^{72}$ states that the top normal level of tryptophan in serum is about $3 \mathrm{mg} / \mathrm{dl}$. In his method, I $\mathrm{mg}$ of tryptophan gave color equivalent to I $\mathrm{mg}$ of cholesterol. We have tested glacial acetic acid, containing ro g/liter of added glyoxylic acid, and have observed a decrease in apparent serum cholesterol values of approximately $40 \%$ when the iron-sulfuric acid reaction was applied either directly to serum or to isopropanol extracts. Addition of $\mathrm{Io} \mathrm{mg} / \mathrm{dl}$ of tryptophan to serum produced no 
detectable increase in the apparent cholesterol levels with either technique. In general, however, direct determinations on serum by the iron-sulfuric acid method gave higher results than when applied to extracts. This is probably a result of slight charring of protein during color development.

(+) Vitamin A. Levels of $\mathrm{I}^{\circ} \mu \mathrm{g} / \mathrm{dl}$ in serum have been reported to increase the apparent cholesterol level by IoO-I50 $\mathrm{mg} / \mathrm{dl}$ when the direct method is employed ${ }^{73}$. Subsequent reports have failed to confirm these findings ${ }^{74}$.

CORTISOL, PLASMA

Cortisol is extracted into dichloromethane, washed with alkali, and mixed with ethanol-sulfuric acid. Fluorescence is measured after Io min.

(+) Benzyl alcohol ${ }^{75}$. Some heparin solutions contain benzyl alcohol as preservative which reacts with an impurity in dichloromethane to produce a similar fluorescence. Interference is significant at Io min and increases markedly by $20 \mathrm{~min}$. The dichloromethane should be spectral grade, or redistilled over concentrated sulfuric acid to eliminate interference ${ }^{76}$.

$(+)$ Spironolactone $^{77}$. Fluorescence emission spectrum is identical to that of cortisol.

\section{CREATININE}

Creatinine reacts with picrate in alkaline solution to form a reddish-brown $\mathbf{I}: \mathbf{I}$ adduct (Jaffe reaction). Complete color development requires $15-20 \mathrm{~min}$ at $25^{\circ}$. Kinetic methods have appeared based on the rate of color development ${ }^{78}$. At elevated temperatures, picrate is reduced to reddish-brown picramate by glucose and other reducing substances. Efforts to improve specificity of the reaction have included ether extraction and/or preliminary treatment with iodine to remove interfering substances (ref. 79). Adsorption of creatinine on Fuller's earth or ion exchange resin has also been employed. Practically, the Jaffe reaction is usually applied directly to urine or proteinfree filtrates without preliminary treatment of specimens. A recent study, applied to urine, indicates that the original Jaffe reaction is the most specific of several procedures investigated $^{80}$. We have evaluated some reported interfering substances by adding alkaline picrate to pure solutions, both in the presence and absence of creatinine. Reaction conditions in our studies were essentially those of Bonsnes and Taussky ${ }^{81}$ with color development for $\mathrm{I}_{5} \mathrm{~min}$ at $25^{\circ}$.

(+) Acetoacetic acid. Reaction with picrate occurs almost immediately ${ }^{78}$. We find that Ioo $\mathrm{mg} / \mathrm{dl}$ of acetoacetic acid produces color equivalent to $3.4 \mathrm{mg} / \mathrm{dl}$ of creatinine. Color development was complete by I min.

(+) Acetone $^{82}$. We find that $500 \mathrm{mg} / \mathrm{dl}$ of acetone produces color equivalent to I.4 $\mathrm{mg} / \mathrm{dl}$ of creatinine.

(+) Aminohippurate ${ }^{83}$. Produces a positive Jaffe reaction but does not interfere at the concentrations obtained during renal studies.

(+) Ascorbic acid ${ }^{84}$. Color development is ascribed to a reducing action. We find that $250 \mathrm{mg} / \mathrm{dl}$ of ascorbic acid produces color equivalent to $\mathrm{I} .9 \mathrm{mg} / \mathrm{dl}$ of creatinine. This concentration could occur in urine but the interference is negligible.

(十) Fructose ${ }^{85}$. We find that rooo $\mathrm{mg} / \mathrm{dl}$ of fructose produces color equivalent to I.o $\mathrm{mg} / \mathrm{dl}$ of creatinine after $\mathrm{I}_{5} \mathrm{~min}$ color development. Extension of incubation time results in marked increase in interference. 
(+) Glucose 82,86 . Reaction appears negligible at $25^{\circ}$. We find that rooo $\mathrm{ml} / \mathrm{dl}$ of glucose produces color equivalent to only $0.2 \mathrm{mg} / \mathrm{dl}$ of creatinine.

(+) Methyldopa. Autoxidation in alkaline solution produces a brown color. We find that Io $\mathrm{mg} / \mathrm{dl}$ of methyldopa produces color equivalent to $\mathrm{I} . \mathrm{o} \mathrm{mg} / \mathrm{dl}$ of creatinine.

$(+)$ Nitrofuran derivatives ${ }^{1}$. These produce a deep orange-brown color in urine specimens.

$(+)$ Phenolsulfomphthalein (PSP). Color is produced in alkaline solution ${ }^{79,87}$. Treatment with zinc in acid solution has been proposed to reduce BSP and PSP to leuco dyes which do not interfere. A separate alkalinized sample blank should also be satisfactory.

$(+)$ Protein ${ }^{83,88}$. We find that $5 \mathrm{~g} / \mathrm{dl}$ of crystalline human serum albumin produces color equivalent to $2.2 \mathrm{mg} / \mathrm{dl}$ of creatinine.

$(+)$ Pyruvate. Produces a positive Jaffe reaction. One $\mathrm{mg}$ of pyruvic acid is reported to produce color only slightly less than I mg of creatinine ${ }^{89,90}$. We find that Io $\mathrm{mg} / \mathrm{dl}$ of pyruvic acid produces color equivalent to $0.3 \mathrm{mg} / \mathrm{dl}$ of creatinine.

(+) Sulfobromophthalein (BSP) ${ }^{79}$. Color is produced in alkaline solution. See under phenolsulfonphthalein.

(O) Taussky ${ }^{91}$ lists a number of compounds that did not interfere when added to protein-free filtrates of serum, followed by treatment with iodine and ether extraction.

\section{ESTROGENS}

A. The following compounds weve found to interfere in a procedure described by Brown ${ }^{92}$, based on fractionation of urinary estrogens and color development with a modified Kober reaction. An additional purification step was included in a subsequent modification that eliminated interference from all those listed ${ }^{93}$.

(-) Cascara. Decreased values for estradiol.

(-) Cortisone. Decreased values for estradiol.

$(+)$ Meprobamate. Increased valucs for estriol.

(1) Phenolphthalein. Increased values for estradiol.

(-) Senna. Decreased values for estrone.

(-) Stilbestrol. Decreased values for estradiol and estriol.

$B$. Methods for determination of estriol in pregnancy urine commonly involve preliminary acid hydrolysis to release the free steroid.

(-) Hydrochlorothiazide. Destroys estriol during acid hydrolysis ${ }^{94}$.

\section{GLUCOSE}

A. Glucose oxidase-peroxidase (GO-POD) methods.

Glucose $+\mathrm{O}_{2} \stackrel{\mathrm{GO}}{\longrightarrow}$ gluconic acid $+\mathrm{H}_{2} \mathrm{O}_{2}$

$\mathrm{H}_{2} \mathrm{O}_{2}+$ chromogen $\stackrel{\text { POD }}{\longrightarrow}$ oxidized chromogen (color)

The first reaction is highly specific for glucose and has been adapted for use with $\mathrm{PO}_{2}$ electrodes. The second reaction is less specific; reducing substances either compete with the chromogen for $\mathrm{H}_{2} \mathrm{O}_{2}$, or keep the chromogen in the reduced state, leading to low results. Somogyi filtrates are recommended to eliminate or minimize 
interferences with determinations on serum. Most major interferences have been observed with paper strip tests applied to urine.

(-) Ascorbic acid. Competes with chromogen ${ }^{95}$.

(-) Bilirubin. Competes with chromogen.

(-) Bilirubin glucuronide. Inhibits reaction ${ }^{96}$.

(-) Formaldehyde. Inhibits reaction. May be added to urine as a preservative.

(-) Glutathione. Competes with chromogen. Not present in serum or Somogyi filtrates of whole blood.

(-) Homogentisic acid. Acts as a reducing substance ${ }^{96}$.

$(+)$ Hypochlorite. Direct oxidation of chromogen. May be present as a contaminant from bleaches, denture cleansers, etc. ${ }^{97}$.

(-) Levodopa. A metabolite, 3,4-dihydroxyphenylacetic acid (DOPAC), acts as a reducing substance ${ }^{98,99}$.

(+) Oxazepam. Reported to act as a $\mathrm{Cu}(\mathrm{II})$-reducing agent and to produce false elevations in a method in which total reducing substances were measured before and after treatment with glucose oxida.se ${ }^{\mathbf{1 0 0}}$. These in vitro findings require further study to rule out possible effects of other ingredients in the capsules.

(-) Phenazopyridine (Pyridium). Reaction is delayed ${ }^{9}$.

(-) Tetracyclines. Parenteral preparations may contain large amounts of ascorbic acid which interferes ${ }^{101}$.

(-) Uric acid. Competes with chromogen.

B. 0 -Toluidine reacts with glucose in hot acetic acid solution to produce a green

color. The reaction is reasonably specific for glucose in serum ${ }^{102}$ and in the average urine specimen ${ }^{\mathbf{1 0 3}}$.

(+) Dextran. Turbidity is produced in acetic acid solution ${ }^{\mathbf{1 0 4}, 105}$.

(+) Disaccharides. Maltose and lactose produce 5 and $33 \%$ as much color, respective$1 y$, as glucose ${ }^{102}$. We have also observed some color production with sucrose, possibly as a result of acid hydrolysis to monosaccharides.

(-) Formaldehyde. Produces an abnormal orange color and reduces the intensity of the grcen color usually produced by glucose in the $o$-toluidine reaction.

$(+)$ Hexoses. Galactose and mannose produce color equivalent to glucose. Fructose does not react ${ }^{102}$.

$(+)$ Pentoses. These produce an orange color with the reagent. The reaction has been applied to measure xylose in urine.

C. Ferricyanide is reduced by glucose in hot alkaline solution to colorless ferrocyanide. The method is reasonably reliable when applied to dialysates of nonuremic serum, but is unsatisfactory for measurements on urine. We have observed increases in apparent glucose values with the following when analyzed in pure solutions.

(+) Creatinine. I $\mathrm{mg}$ is equivalent to I $\mathrm{mg}$ glucose.

(t) Uric acid. I $\mathrm{mg}$ is equivalent to $0.5 \mathrm{mg}$ glucose.

D. Copper-reduction methods. Numerous modifications have been proposcd. For whole blood glucose, a Somogyi filtrate provides greatest specificity. For serum glucose, a Foline-Wu filtrate is about equally satisfactory. Uric acid has been shown to produce color equivalent to $75 \%$ of glucose by the Folin-Wu method but no color with the Nelson-Somogyi method. Glucuronic acid, however, appears in substantial amounts in either filtrate ${ }^{106}$.

The following interferences refer almost entirely to the measurement of total

Clin. Chim. Acta, 4I (I972) 395-434 
reducing substances in urine, either with Benedict's reagent or Clinitest tablets (Ames Co.). Such determinations are done primarily as semiquantitative tests for glucose in urine but are also helpful to detect pentosuria, lactosuria, etc., where glucose oxidase strips would be negative. Concentrations of reagents are adjusted to produce "negative" or trace reactions for reducing substances, such as creatinine and uric acid, normally present in urine.

(十) Aminopyrine. Glucuronide metabolite ${ }^{107}$.

(士) Amino acids. Variable interference with high concentrations. Effect in urine specimens is probably negligible ${ }^{108}{ }^{109}$.

(+1.) $p$-Aminosalicylate. Probably excreted as a metabolite, similar to gentisic acid ${ }^{110}$.

$(+)$ Ascorbic acid. Positive test with concentrations of $50 \mathrm{mg} / \mathrm{dl}^{95}$.

(+) Cephalothin (Keflin). Produces a blackish-brown color with Clinitest tablets.

$(+)$ Chloral hydrate. A metabolite, trichloroethanol, is excreted as the glucuronide.

(+) Chloramphenicol (Chloromycetin) ${ }^{111}$.

$(+)$ Chlortetracycline (Aureomycin) ${ }^{111}$.

(+) Cinchophen ${ }^{112}$.

(十) Formaldehyde ${ }^{110}$.

(t) Fructose ${ }^{113}$.

(十) Glucosamine ${ }^{113}$.

(+) Glucuronide metabolites. Present in blood or urine and act as reducing agents ${ }^{114}$.

(+) Homogentisic acid ${ }^{110}$.

(t) Indican ${ }^{115}$.

$(+)$ Isoniazid ${ }^{110}$.

(+) Levodopa. A major metabolite, DOPAC, is a reducing agent ${ }^{98,99}$.

$(+)$ Metaxalone $^{15}$.

(+) Nalidixic acid. Appears as glucuronide in both blood and urine $\mathrm{e}^{116}$.

$(+)$ Neocinchophen (Tolysin) ${ }^{\mathbf{1 1 2}}$.

(+) Nitrofuran derivatives. Metabolites act as reducing agents ${ }^{1}$.

$(+)$ Oxazepam. Reported to reduce $\mathrm{Cu}(\mathrm{II})$ in Somogyi method ${ }^{100}$.

$(+)$ Oxytetracycline (Terramycin) ${ }^{111}$.

$(+)$ Penicillin. Drug and degradation products, in high concentrations, act as reducing agents ${ }^{10,117}$.

$(+)$ Probenecid ${ }^{15}$.

(+) Radiographic contrast media. Urine may produce a greenish-black reaction $2-20 \mathrm{~h}$ after administration of sodium diatrizoate (Hypaque) ${ }^{118}$. The drug alone does not react unless uric acid or creatine is present.

$(+)$ Reducing sugars (other than glucose). These include fructose, galactose, lactose, maltose, rhamnose, ribose, and xylose ${ }^{110,113}$.

$(+)$ Saccharoids. In whole blood these reducing substances are principally glutathione and ergothioneine. Increased glucuronic acid is reported in the blood of diabetics (ref. IIg).

(+) Salicylates. A metabolite, gentisic acid, is a reducing agent ${ }^{112}$.

(+) Streptomycin. Drug and metabolites are reducing agents ${ }^{120}$.

(-) Sulfanilamide. Forms a colorless, soluble Cu(II) complex ${ }^{121}$.

$(+)$ Sulfathiazole. Forms a yellow to orange complex in alkaline urine ${ }^{121}$.

$(+)$ Vaginal powders. May contain glucose ${ }^{1}$. 
HOMOVANILLIC ACID

Homovanillic acid in urine is isolated by chromatography, then oxidized and converted to a fluorescent derivative.

$(+)$ Salicylate ${ }^{122}$. Interfering fluorescence is caused by acetylsalicylic acid, salicylic acid and an unidentified metabolite. Blank readings are increased 50-Ioo fold.

\section{I7-HYDROXYCORTICOSTEROIDS}

This group of steroids $(\mathrm{r} / \mathrm{-OH})$ is commonly determined by the Porter-Silber reaction ${ }^{123,124}$. Following enzymatic hydrolysis with $\beta$-glucuronidase, the free steroids are extracted into chloroform, washed with dilute alkali, then re-extracted into a strongly acid solution of phenylhydrazine. The absorbance of the yellow derivative is measured at 4 Io $\mathrm{nm}$. (I7-Ketogenic steroids are discussed under $\mathrm{I}$-ketosteroids. See also cortisol, plasma).

The most extensive single study on drug interference in steroid determinations is that of Borushek and Gold ${ }^{14}$. Determinations were made in vitro on solutions of 23 drugs, both alone and in the presence of standards, and on 24 -h urine collections from patients before and after receiving the medications. Observations reported include absorbance produced by the drug alone, increased or decreased absorbance of standard in the presence of the drug, and apparent increase or decrease in urinary steroid excretion following administration of the drug. Only drugs showing the latter effect are included below.

(t) Acetone. Reported to interfere ${ }^{\mathbf{1 2 5}}$.

$(+)$ Chlordiazepoxide (Librium) ${ }^{\mathbf{1 4}}$.

(-) Chlorpromazine (Thorazine) ${ }^{\mathbf{1 4}, \mathbf{1 2 6}}$.

$(+)$ Colchicine $^{127}$.

(+) Chloral hydrate ${ }^{128}$. Produces color in the Porter-Silber reaction with butanol as extractant but not with chloroform ${ }^{127}$.

(+) Etryptamine (Monase) ${ }^{\mathbf{1 4}}$.

$(+)$ Hydroxyzine (Atarax ${ }^{14}$. A brownish-yellow color is produced.

$(+)$ Meprobamate (Equanil) ${ }^{\mathbf{1 4}}$.

$(+)$ Methenamine mandelate (Mandelamine) ${ }^{129}$. Produces formaldehyde which causes an apparent increase in value unless the Allen correction as applied to absorbance readings.

(+) Paraldehyde ${ }^{127,128}$.

(+) Penicillin G. Produces a similar color reaction $\mathbf{1}$.

(-) Pentazocine (Talwin) ${ }^{13}$. Administration of Ioo $\mathrm{mg} /$ day decreased apparent $\mathbf{I} 7$ $\mathrm{OH}$ excretion approximately $\mathrm{I} 6 \%$. This may be a pharmacologic effect.

(+) Potassium iodide ${ }^{128}$. Excreted in urine and produces a yellow color in the PorterSilber reaction with butanol as extractant but not with chloroform ${ }^{127}$.

(-) Prochlorperazine (Compazine) ${ }^{126}$. An abnormal yellow-orange to pink color appears in both the urine blank and test solutions. Subtraction of the blank does not provide adequate correction.

(-) Promethazine (Phenergan) ${ }^{120}$. Effect is similar to prochlorperazine.

(-) Propoxyphene (Darvon) ${ }^{13}$. Administration of $195 \mathrm{mg} /$ day decreased apparent $\mathrm{I} 7-\mathrm{OH}$ excretion by $\mathrm{I} 8 \%$. This may be a pharmacologic effect since the drug had no effect in vitro. 
(+) Quinine ${ }^{127}$

(-) Reserpine (Serpasil) ${ }^{14}$. This may be a pharmacologic effect since the drug produces an orange-red color in the final reaction mixture and contributes to absorbance.

(-) Salicylates ${ }^{130}$. Following large doses, salicylate glucuronide in urine acts as a competing substrate for glucuronidase. Complete hydrolysis of conjugated steroids requires more enzyme and prolonged incubation times.

$(+)$ Spironolactone (Aldactone) ${ }^{131}$. The drug or its metabolite produces a similar color reaction.

$(+)$ Triacetyloleandomycin ${ }^{132}$. Administration of $\mathrm{I}$ or $2 \mathrm{~g} /$ day increased apparent I7-OH excretion by 2 to 4 -fold. Addition of $0.25 \mathrm{~g}$ to a 24 -h urine specimen elevated the apparent value from 2.9 to I0.5 $\mathrm{mg}$.

\section{5-HYDROXYINDOLEACETIC ACID (5-HIAA)}

A. Screening test on urine. A purple color is developed by reaction with $\mathrm{I}_{-}$ nitroso-2-naphthol and nitrous acid ${ }^{133}$. This reaction is said to be specific for 5-hydroxyindoles. Extensive work by Mustala ${ }^{134}$, however, has defined the chemical configuration necessary for color development in the reaction ${ }^{131}$.

$(+)$ Acetanilide $^{133}$. A metabolite, $p$-hydroxyacetanilide, produces similar color. This drug is little used at present.

(+) Bananas ${ }^{135}$. Ingestion of 3 bananas per day doubled the normal excretion of 5-HIAA. Apparently this is a true increase in excretion.

(-) Formaldehyde. Released from various drugs. Inhibits color development ${ }^{136}$.

(+) Glyceryl guaiacolate (Robitussin) ${ }^{134,137}$.

(-) Keto acids ${ }^{138}$. Excessive amounts interfere with color formation.

(+) Mephenesin and mephenesin carbamate ${ }^{139}$. Metabolite reacts to produce color.

(-) Methenamine mandelate ${ }^{\mathbf{1 3}}$. Releases formaldehyde. See above.

(+) Methocarbamol129. Metabolite reacts to produce color.

$(+)$ Phenacetin. Produces the same metabolite as acetanilide.

(-) Phenothiazines ${ }^{140}$. Compounds inhibit color development.

B. Quantitative tests. Urine is treated with dinitrophenylhydrazine to remove keto acids. 5-HIAA is extracted, purified, and reacted with the same reagents as in the screening test. By the method of Udenfriend $e t a{ }^{138}$, metabolites of mephenesin, methocarbamol and glyceryl guaiacolate produce falsely elevated results. By permitting the final solution to stand to allow fading of some interfering colors, and by reading absorbance at two wavelengths, Mustala claims to have eliminated or detected interference from these compounds ${ }^{134,141}$.

IODINE UPTAKE, RADIOACTIVE (See thyroid function tests.)

KETONE BODIES (URINE)

This category includes qualitative tests for acetone and acetoacetic acid (diacetic acid), anll for plenylpyruvic acid.

A. Gerhardt test. Ferric chloride reacts with acetoacetic acid to produce a red color. Concentrations greater than $25-50 \mathrm{mg} / \mathrm{dl}$ give a positive test.

$(+)$ Phenothiazines. Metabolites form a pink or purple color with the reagent ${ }^{142}$.

Clin. Chim. Acta, 4x (I972) 395-434 
$(+)$ Salicylates ${ }^{\mathbf{1 4 3}}$. Produce a red color. Interference from these and other drugs is detected by boiling acidified urine to destroy acetoacetic acid, then retesting.

$B$. Nitroprusside plus alkali. This reagent reacts principally with acetoacetic acid to form a purple color. A reagent tablet or test strip is commonly used (Acetest tablets or Ketostix, Ames Co.). The test is sensitive to approximately Io $\mathrm{mg} / \mathrm{dl}$ of acetoacetic acid or Ioo $\mathrm{mg} / \mathrm{dl}$ of acetone ${ }^{\mathbf{1 4 4}}$. Salicylates do not interfere ${ }^{\mathbf{1 4 3}}$.

$(+)$ Levodopa and methyldopa. Produce color with the reagent ${ }^{145,146}$.

(+) Paraldehyde. Acetaldehyde produces color with the reagent ${ }^{\mathbf{1 4 7}}$.

(-) Phenazopyridine (Pyridium). Slightly positive reactions are masked by the color of the drug'.

(+) Phenolsulfonphthalein (PSP). Reddish-purple color with alkali.

$(+)$ Phenylpyruvic acid (large quantities). Present in urine from patients with phenylketonuria.

(t) Sulfobromophthalein (BSP). Partially excreted in the urine and produces a purple color with alkali.

$C$. A screening test for phenylketonuria consists of adding a solution of ferric chloride to urine to produce a transient blue-green color with phenylpyruvic acid.

(-) Levodopa ${ }^{148}$. Urine from patients receiving $\mathrm{I}-5 \mathrm{~g} /$ day became a dark, muddy black-brown color upon addition of ferric chloride.

(土) Phenothiazines ${ }^{\mathbf{1 4 2}}$. Metabolites form a pink or purple color with the reagent which may mask true color of the test.

(士) Salicylates ${ }^{142}$. A red color is produced which may mask the true color of the test.

\section{I7-KETOSTEROIDS AND Y7-KETOGENIC STEROIDS}

I7-Ketosteroids (I7-KS) are commonly measured by some modification of the Zimmerman reaction. Following acid hydrolysis, the free steroids are extracted into a nonpolar solvent and washed with alkali. A portion of the extract is evaporated and the steroids reacted with $m$-dinitrobenzene in alcoholic alkaline solution. The absorbance, after development of the red-purple color, is measured at $520 \mathrm{~nm}$. 3-Ketosteroids and 20-ketosteroids also react but produce less color than $\mathbf{I} 7$-KS.

I7-Ketogenic steroids (I7-KGS) include the I7-hydroxycorticosteroids (discussed separately) as well as certain other steroids, such as pregnanetriol, with a I7hydroxy, 20,2I-side chain. These compounds may be oxidized to I7-KS by treatment with sodium bismuthate in acetic acid solution, then measured by the usual Zimmerman reaction. Pre-existing $I 7$-KS are determined separately and subtracted from the total to provide a measure of I7-KGS. In subsequent modifications, pre-existing I7$\mathrm{KS}$ are eliminated by reduction with borohydride prior to bismuthate oxidation ${ }^{\mathbf{1 4 9}}$. Metaperiodate may be substituted for bismuthate as an oxidizing agent.

The following refer mainly to interferences encountered in actual urine specimens, rather than to reactions with pure drugs.

(+) Acetone ${ }^{150}$. Produces a brown color in the Zimmerman reaction.

(-) Chlordiazepoxide (Librium) ${ }^{14}$. Apparent decrease in I7-KS excretion. This may be a pharmacologic effect since the pure drug forms a pink color in the reaction and contributes to the absorbance.

( \pm ) Chlorothiazide (Diuril) ${ }^{151}$. Reported to interfere but not confirmed by in vivo studies ${ }^{14}$. 
$(+)$ Chlorpromazine (Thorazine) $)^{14}$. Produces a red color in the Zimmerman reaction.

(+) Cloxacillin ${ }^{152}$. Produces a purple color in the Zimmerman reaction.

(士) Dextroamphetamine (Dexedrine) ${ }^{151}$. Reported to interfere but not confirmed by in vivo studies ${ }^{14}$.

$(+)$ Ethinamate (Valmid) ${ }^{14}$. Produces a deep red color in the Zimmerman reaction.

$(+)$ Etryptamine (Monase) ${ }^{14}$. Slight increase in $\mathrm{I}_{7}$-KS values reported with in vivo studies.

(-) Glucose $\mathrm{e}^{152}$. In the I7-KGS methods, excess glucose acts as a reducing agent to consume bismuthate or metaperiodate, resulting in possible incomplete oxidation of the steroid side chain. Glucose can be eliminated by yeast fermentation, by increasing the concentration of oxidant, or by preliminary extraction of the steroids with ether-ethanol $(3: \mathrm{I})$. The latter approach is most reliable ${ }^{49}$,

(t) Glutethimide (Doriden) ${ }^{151}$. Reported to interfere but not confirmed by in vivo studies ${ }^{14}$.

(+) Meprobamate (Equanil) ${ }^{153,15 *}$. Produces a yellow color in the Zimmerman reaction. Absorbance corrections, based on readings at 2 or 3 wavelengths, all yield false low results.

(-) Metyrapone (Metopirone) ${ }^{152}$. In rare cases a metabolite appears to compete with I7-KS for $m$-dinitrobenzene.

(+) Nalidixic acid ${ }^{155}$. Produces an orange color in the Zimmerman reaction. A similar reaction was demonstrated in vitro.

$(+)$ Paraldehyde ${ }^{151}$. Reported to interfere.

$(+)$ Penicillin $\mathrm{G}^{156}$. Drug is excreted largely unchanged and behaves as a ketogenic chromogen. Apparent $I_{7}$-KS and $I_{7}$-KGS excretion are both increased but the latter is more striking.

(+) Phenaglycodol157. The drug itself does not give the Zimmerman reaction but. during acid hydrolysis of conjugated I7-KS the drug undergoes a pinacol rearrangement to form a ketone which does react.

(土) Phenazopyridine (Pyridium) ${ }^{151}$. Reported to interfere but not confirmed by in vivo studies ${ }^{\mathbf{1 4}}$.

(士) Prochlorperazine (Compazine) ${ }^{151}$. Reported to interfere but not confirmed by in vivo studies ${ }^{14}$.

(-) Propoxyphene (Darvon) ${ }^{13}$. Administration of $195 \mathrm{mg} /$ day decreased apparent I7-KS excretion by $29 \%$. This may be a pharmacologic effect since the drug had no effect in vitro.

$(+)$ Quinine ${ }^{151}$. Reported to interfere.

(-) Radiographic contrast media ${ }^{158}$. Studies were made with meglumine iodipamide (Duografin) and meglumine iothalamate (Conray). Mean I7-KGS values fell from 9.3 to $3.5 \mathrm{mg} /$ day after administration. The compounds act as reducing agents, similar to glucose. Preliminary extraction of urine with ether-alcohol eliminated the interference.

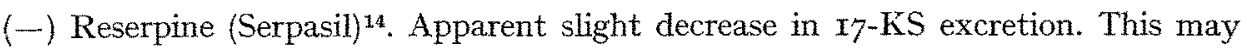
be a plarmaculugic effect. The fual reaction mixture has an orange color and should contribute to absorbance.

(十) Spironolactone (Aldactone) ${ }^{131}$. Produces a similar color reaction.

(+) Trjacetyloleandomycin ${ }^{132}$. A false increase in $\mathrm{I} 7$-KS values was observed in pa-

Clin. Chim. Acta, $4^{\mathrm{I}}$ (1972) $395-434$ 
tients receiving $\mathrm{I}-2 \mathrm{~g} /$ day. Addition of $0.25 \mathrm{~g}$ to a 24 -h urine specimen elevated the apparent I7-KS value from 9.7 to $18.0 \mathrm{mg}$.

(+) Urinary chromogens. Various naturally occurring pigments are extracted and produce color in the Zimmerman reaction. This interference can be effectively eliminated by adding formaldehyde to urine prior to acid hydrolysis ${ }^{159}$.

\section{LACTIC DEHYDROGENASE}

This enzyme catalyzes the reaction:

$$
\text { Lastate }+\mathrm{NAD}^{+} \rightleftharpoons \text { Pyruvate }+\mathrm{NADH}+\mathrm{H}^{+}
$$

Colorimetric assays using the pyruvate-to-lactate reaction and measuring the disappearance of pyruvate with the dinitrophenylhydrazine reaction will give low results if $\mathrm{NADH}$ is omitted from standard solutions of pyruvate. Pyridine nucleotides react with the reagent to yield a product which absorbs maximally at the same wavelength as pyruvate. The nucleotide competes for the color reagent with increasing effectiveness as the pyruvate concentration decreases during the reaction ${ }^{160}$.

LIPASE

In the turbidimetric method of Vogel and Zieve ${ }^{161}$, serum lipase activity is related to the decrease in absorbance observed during incubation of an olive oil emulsion.

$(+)$ Bilirubin ${ }^{162}$. Apparent lipase activity was shown to be elevated in proportion to the concentration of bilirubin. A titrimetric method was not affected. The interfering substance, presumably bilirubin, can be removed with DEAE cellulose.

\section{MAGNESIUM}

Magnesium reacts with Titan Yellow in alkaline solution to produce a pink complex which is measured spectrophotometrically.

(-) Gluconate ${ }^{163}$. Administration as the calcium salt resulted in falsely low results by the Titan Yellow procedure but not in methods involving phosphate precipitation or preliminary ashing. The effect was confirmed in vitro.

METANEPHRINES (See catecholamines.)

\section{PHOSPHATASE, ALKALINE}

(+) Albumin infusions ${ }^{164,165}$. Albumin prepared from human placentas contains heatstable alkaline phosphatase. In one case, the serum alkaline phosphatase rose to I6o Bodansky units after multiple infusions and remained elevated for Io days following cessation of therapy ${ }^{\mathbf{1 6 4}}$. Manufacturers vary in whether or not they use only venous blood as a source of albumin ${ }^{166}$. The heat-stable enzyme may be detected by incubating serum at $60^{\circ}$ for $\mathrm{I} h$ to destroy alkaline phosphatase of non-placental origin.

(-) Albumin infusions. In contrast to the above, albumin prepared from venous 
blood appears to inhibit serum alkaline phosphatase ${ }^{168}$. The effect could be demonstrated in vitro with more than one method of assay. Addition of magnesium partially reversed the inhibition.

(+) Sulfobromophthalein (BSP). This dye could interfere in methods based on final color development in alkaline solutions, depending on the wavelength used to measure absorbance ${ }^{168}$.

PHOSPHATE, INORGANIC

Inorganic phosphate, in a protein-free filtrate of serum, reacts with molybdate to form phosphomolybdate which, in turn, is reduced to a molybdenum blue complex by aminonaphtholsulfonic acid or other suitable reducing agents. The following compounds, if present, complex with molybdate and prevent full color development ${ }^{\mathbf{1 6 9}}$. (-) Citrate.

(-) Mannitol. The compound has been used to promote diuresis. Levels reached in plasma should not interfere ${ }^{170}$.

(-) Oxalate.

(-) Tartrate.

PORPHYRINS

A screening test for urinary coproporphyrins is performed by adding acetic acid to urine and extracting with ether. Coproporphyrins in the ether layer are detected by their pink fluorescence in ultraviolet light.

(+) Phenazopyridine (Pyridium). Colors the urine orange-brown and is often mistaken for porphyrins. The interference is eliminated by adding a small amount of sodium dithionite $\left(\mathrm{Na}_{2} \mathrm{~S}_{2} \mathrm{O}_{4}\right)$ to the urine prior to extraction ${ }^{9}$.

(+) Tetracycline ${ }^{171}$. A pink fluorescence is observed when both tetracycline and phenazopyridine are present together. Neither drug alone was found to interfere in the screcning test.

\section{PREGNANCY TESTS}

These tests depend on the measurement of human chorionic gonadotropin $(\mathrm{HCG})$ in urine in early pregnancy. Biologic pregnancy tests employ animals, such as frogs, rats, and rabbits. More recently, immunologic tests utilizing latex particles or erythrocytes, coated with HCG, and an antiserum to HCG have been developed. When these are mixed together, agglutination occurs. When HCG in the urine of a pregnant woman is added to the system the antiserum (anti-HCG) is neutralized and agglutination does not occur. Thus, agglutination-inhibition is interpreted as a positive test. Various commercial reagent kits and modifications are available.

$(+)$ Phenothiazines. False positive frog tests were reported in 8 of 19 patients receiving promazine (Sparine) and in 5 of II patients receiving chlorpromazine (Thorazine). Use of serum, rather than urine, was recommended ${ }^{172}$. Onc report describes a false positive immunologic test on urine from a patient receiving chlorpromazine ${ }^{173}$. The test became negative 2 weeks after the drug was withdrawn. At the time of the positive test, however, the patient also showed $2+$ pro- 
teinuria which could be responsible for the false positive. In subsequent reports, false positive immunologic tests were attributed to phenothiazines for some reagent kits ${ }^{174}$; other investigators were unable to demonstrate either false positive or false negative results associated with phenothiazine medication ${ }^{175}$. Release of luteinizing hormone (T.H) or interstitial cell stimulating hormone (ICSH), following phenothiazine therapy, has been suggested as a possible mechanism for false positive pregnancy tests ${ }^{176,177}$. Both hormones cross-react with anti-HCG.

(+) Protein. A number of reports described false positive immunologic tests for pregnancy attributed to protein in urine ${ }^{178-180}$. Presumably these were caused by contamination of commercial HCG preparations with other antigenic proteins ${ }^{181}$.

PROTEIN (SERUM)

A. Biuret reaction. A violet color is produced with alkaline-Cu(II)-tartrate reagent. Absorbance is measured near $550 \mathrm{~nm}$.

$(+)$ Bilirubin. Effect is negligible except in extreme jaundice. We have observed that a bilirubin level of $20 \mathrm{mg} / \mathrm{dl}$ increases the apparent total protein by approximately o.I $\mathrm{g} / \mathrm{dl}$.

(+) Dextran. Produces a fine turbidity with $\mathrm{Cu}(\mathrm{II})$; hence, a separate serum blank correction is inadequate ${ }^{22}$. Solutions should be observed for a Tyndall effect. Ethylene glycol may be incorporated in biuret reagent to eliminate interference ${ }^{182}$.

(+) Hemoglobin. Reacts with biuret reagent but also contributes directly to absorbance. The color produced in the biuret reaction by I $\mathrm{mg}$ of hemoglobin is equivalent to $\mathrm{I.9} \mathrm{mg}$ of serum protein ${ }^{183}$.

$(+)$ Lipemia. Various blank corrections have been proposed. The most satisfactory approach seems to be ether extraction ${ }^{184}$.

$(+)$ Phenazopyridine (Pyridium). Orange-brown color contributes to absorbance ${ }^{9}$.

(t) Sulfobromophthalein (BSP). Similar color is produced in alkaline solution. We have observed that a plasma level of $2 \mathrm{mg} / \mathrm{dl}$ (corresponding to $20 \%$ retention of BSP) increases the apparent total protein by $0.3 \mathrm{~g} / \mathrm{dl}$.

B. Dye binding procedures for albumin. For example, 2-(4'-hydroxyazobenzene) benzoic acid (HABA) produces color with albumin in buffer solution at $\mathrm{pH} 5$. Absorbance is measured at $505 \mathrm{~nm}$.

(-) Bilirubin. Competes with HABA for binding sites on albumin ${ }^{\mathbf{1 8 5}}$. Effect is offset to some extent since bilirubin also has significant absorbance at $505 \mathrm{~nm}$. The latter effect is eliminated with bromcresol green methods where absorbance is measured at $600 \mathrm{~nm}^{186}$.

(十) Heparin. Presumably promotes binding of dye to globulins ${ }^{187}$. Thus, a series of corresponding sera and heparinized plasma showed mean values of 4.2 and 9.I $\mathrm{g} / \mathrm{dl}$ respectively. We have not been able to demonstrate such interference with the dye SpecTru AB2 (Pierce Chemical Co., Rockford, Ill.).

(-) Penicillin. Presumably competes with HABA for binding sites on albumin ${ }^{\mathbf{1 8 5}}$. Interference is usually negligible.

(+) Phenazopyridine (Pyridium). Contributes to absorbance. Serum blanks are required in the HABA procedure.

(-) Salicylate. Competes with HABA for binding sites on albumin ${ }^{185,187}$. Two hours 
following ingestion of 4 aspirin tablets ( $\mathrm{I} .3 \mathrm{~g}$ ), the apparent serum albumin level was reported to decrease by $14 \%$.

(-) Sulfonamides. The mechanism is similar to that of salicylate ${ }^{185}$.

C. Electrophoresis of serum proteins.

$( \pm)$ Iodinated radiographic contrast media. At serum levels expected during diagnostic studies, the peaks due to albumin and to $\alpha$-and $\beta$-globulins flatten or disappear. A high peak appears in the $\gamma$-globulin region ${ }^{188}$.

$( \pm)$ Penicillin. High doses, given intravenously, are reported to cause formation of bis-albumin ${ }^{1.89}$. The penicillin-albumin complex has greater electrophoretic mobility than normal albumin.

PROTEIN (CEREBROSPINAL FLUID)

A. Turbidimetric methods based on addition of sulfosalicylic acid or trichloroacetic acid. Henry et al. have reported that albumin produces 2.4 times as much. turbidity as globulin with sulfosalicylic acid reagent ${ }^{190}$. With trichloroacetic acid, globulin produces about $20 \%$ greater turbidity than albumin. A mixed reagent was recommended. Pennock et al. ${ }^{191}$ recommend a mixture of sulfosalicylic acid and sodium sulfate with which the turbidity produced is independent of the relative concentrations of albumin and globulin.

$(+)$ Bilirubin. Absorbance due to bilirubin is especially significant near $460 \mathrm{~nm}$. This can be minimized, but with some loss in sensitivity for turbidimetric measurements, by using wavelengths above $500 \mathrm{~nm}$. In addition, a sample blank should be included for xanthochromic fluids.

B. Methods based on the use of alkaline-Cu(II)-tartrate and Folin-Ciocalteu reagent (phosphotungstic-phosphomolybdic acid). A blue color is produced. The FolinCiocalteu reagent alone reacts with phenols in general and considerable drug interference can be expected. Results spuriously high by as much as $67 \mathrm{mg} / \mathrm{dl}$ have been reported. A deproteinized sample blank is recommended ${ }^{\mathbf{1 9 2}}$. The following substances have been reported to produce falsely elevated values, or color with the reagent ${ }^{192-194}$. Figures in parentheses show the apparent $\mathrm{mg}$ increase in protein per $\mathrm{mg}$ of substance tested.

$(+) p$-Aminobenzoate (I.8)

$(+) p$-Aminosalicylate (4.0)

(+) Chloramphenicol (o.I)

$(+)$ Chlorpromazine $(0.5)$

$(+)$ Epinephrine (I.5)

(+) 5-Hydroxyindoleacetic acid (3.2)

(+) 5-Hydroxytryptophane (3.9)

(+) Imipramine (Tofranil) (3.5)

(1) Oxytetracycline (Terramycin) (2.4)

$(+)$ Penicillin (0.5)

(+) Phenacetin (o.I)

$(+)$ Salicylate (2.3)

$(+)$ Serotonin (3.I)

$(+)$ Streptomycin (0.3)

$(+)$ Sulfonamides $(0.3-0.6)$

Clin. Chim. Acta, 4I (1972) 395-434 
(+) DL-Thyronine (2.9)

$(+)$ Tyramine (2.7)

$(+)$ Tyrosine $(3 \cdot 3)$

PROTEIN (URINE)

Quantitative methods are usually similar to the turbidimetric methods for cerebrospinal fluid. A suitable blank must be included to correct for absorbance by urinary pigments. The following observations pertain to qualitative tests for protein in urine.

A. Precipitation of protein with sulfosalicyclic acid or trichloroacetic acid, or by heating urine at $\mathrm{pH}_{4}$ to 5 . Certain drugs, metabolites, or diagnostic agents may precipitate under these conditions. Of these methods, the heat test appears to be the most specific for protein.

(+) $p$-Aminosalicylic acid ${ }^{195}$.

(+) Cephalothin and cephaloridine ${ }^{198}$.

$(+)$ Iodinated radiographic contrast media ${ }^{197-201}$.

(+) Penicillin 111,117 .

(+) Tolbutamide metabolite ${ }^{201-303}$.

$B$. Indicator tablets or strips. These methods are based on the so-called protein error of indicators. The test reagent is bromphenol blue buffered to a $\mathrm{pH}$ of about 3 . Color changes from yellow to blue in the presence of protein. These are available commercially as Albustix strips and Albutest tablets (Ames Co.). Sensitivity is about 20-30 $\mathrm{mg}$ protein/dl and the specificity appears better than with precipitation techniques. The strips are not affected by radiographic contrast media.

$(+)$ Alkaline urine. Urine must be highly buffered and strongly alkaline to overcome buffer action of the strips or tablets. Such interference is rare ${ }^{201}$.

PROTEIN-BOUND IODINE (See thyroid function tests.)

PROTHROMBIN

Plasma prothrombin activity is estimated by means of the prothrombin clotting time. In the one-stage method, developed by Quick, oxalated plasma is mixed with excess thromboplastin and a predetermined amount of calcium ion. The time for clot formation is measured and compared with that for a normal control.

Alterations in clotting time associated with drug administration are not the result of test interferences, but rather arise from true changes in plasma levels of prothrombin, caused by interactions of other drugs with anticoagulants. The anticoagulants are carried in plasma bound to protein, mainly albumin, from which they can be displaced by competing drugs such as salicylates, phenylbutazone, oxyphenbutazone, indomethacin, and some sulfonamides ${ }^{1}$. Increased amounts of active anticoagulant are thus made available and the prothrombin time is increased. Conversely, withdrawal of such drugs in a patient stabilized on anticoagulant therapy releases binding sites, leading to subsequent decrease in available anticoagulant, and a decrease in prothrombin time. 
In addition, some drugs induce formation by the liver microsomes of enzymes which metabolize not only the drugs but other substrates. Barbiturates, for example, induce enzymes which metabolize coumarin, reducing its effect and decreasing prothrombin time. Sudden withdrawal of these drugs from patients stabilized on the drug and an anticoagulant may lead to a rapid and serious increase in prothrombin time, associated with a fall in prothrombin levels. These potentially serious interactions, which occur frequently but have often been unanticipated, are described thoroughly in recent reviews by Sigell and Flessa ${ }^{2 n 4}$ and by Koch-Woser and Scllcrs ${ }^{205}$.

PSP TEST

Phenolsulfonphthalein (PSP, phenol red) is injected intravenously. The amount excreted in the urine during a timed interval provides an index of kidney function. The urine is made alkaline to develop a reddish-violet color which is measured spectrophotometrically.

(+) I,8-Dihydroxyanthraquinone (Danthron) ${ }^{2 n 6}$. This peristaltic stimulant is a red dye which is absorbed and excreted in the urine to produce an apparent higher excretion of PSP.

(+) Ethoxazene (Serenium). Colors the urine orange-red.

(-) Penicillin ${ }^{207}$. Competes with PSP for excretion by the kidney.

(+) Phenazopyridine (Pyridium) ${ }^{9}$. Colors the urine orange-brown. Removed by butanol extraction after adding alkali.

(-) Salicylates ${ }^{207}$. Compete with PSP for excretion by the kidney.

$(+)$ Sulfobromophthalein (BSP). Excreted partly by the kidney and produces a color with alkali similar to PSP. The two tests should not be performed at the same time.

(-) Sulfonamides ${ }^{2 n}$. Compete with PSP for cxcrction by the kidney.

\section{SPECIFIC GRAVITY (URINE)}

(+) Radiographic contrast mediatos. We have observed urine specific gravities as high as 1.075 following intravenous injection of diatrizoate (Hypaque).

$\mathrm{T}_{3}$ AND $\mathrm{T}_{4}$ TESTS (See thyroid function tests.)

\section{THYMOL TURBIDITY}

A buffered solution of thymol is mixed with serum. Increased turbidity is observed with serum from patients with hepatocellular damage, especially those with infectious hepatitis.

(-) Heparin. Thymol turbidity, measured on either plasma or serum, decreased from I7 units to $3-5$ units as heparin concentration was increased from zero to $0.5 \%$ (refs. 209, 2Io). Thus, the effect appears to be related to heparin, rather than to differences in plasma and serum. We have observed failure to develop adequate turbidity in oxalated plasmas when compared to corresponding serums. 
THYROID FUNCTION TESTS*

Methodology is discussed by Berger ${ }^{211}$. The special problem of interference by iodine-containing substances has been reviewed by Rapport and Curtis ${ }^{212}$, and by Liewendahl ${ }^{213}$. In this section we have also included a number of pharmacologic effects since, in some cases, the exact mechanism of alteration of values is obscure. Either category of results could be misleading, when arriving at a diagnosis.

$A$. Protein-bound iodine ( $P B I)$. Serum proteins are precipitated and washed to remove inorganic iodine. Sodium carbonate is added, to minimize loss of iodine in the ashing step, and the precipitate is incinerated to destroy organic matter and to convert thyroxine iodine to inorganic iodide, which is quantitated by its catalytic effect on the ceric-arsenite reaction ${ }^{214}$. The Technicon procedure for automated determination substitutes digestion by a mixture of sulfuric, nitric, and perchloric acids for the alkaline ashing step. PBI procedures have been reviewed by Chaney ${ }^{\mathbf{2 1 5}}$. Davis ${ }^{\mathbf{2 1 6}}$, and recently Acland $^{217}$, have reviewed the factors affecting the PBI test. Major classes of drug interference include iodine-containing compounds and substances which affect the amount of thyroxine $\left(T_{4}\right)$ in transport.

(O) Acetazolamide. No effect on test 218 .

(-) $p$-Aminobenzoate. Antithyroid activity has been suggested ${ }^{219}$.

(-) Aminoglutethimide. Competes for $\mathrm{T}_{4}$ binding sites ${ }^{1}$.

(-) $p$-Aminosalicylate. Antithyroid activity has been suggested ${ }^{20-222}$.

(-) Androgens, anabolic steroids. These decrease the level of thyroxine-binding globulin (TBG), thus decrease total $\mathrm{T}_{4}{ }^{223}$.

(-) Barbiturates. Compete with $\mathrm{T}_{4}$ for TBPA sites ${ }^{\mathbf{2 2 4}, \mathbf{2 2 5}}$.

(t) Barium sulfate. Sometimes contaminated with iodine ${ }^{212}$.

$(+)$ Bromides. Some preparations contain iodide as a contaminant ${ }^{220}$. Three of 6 patients given massive doses of pota.ssium bromide-ammonium bromide showed elevated $\mathrm{PBI}{ }^{226}$.

(O) Busulfan. Normal PBI levels observed in 2 individuals following long-term administration ${ }^{22}$.

(O) Calcium. Calcium loading and subsequent withdrawal had no effect on test in 7 subjects $^{228}$.

(-) Chlorpromazine. Reports are conflicting. In one experiment, 5 patients given $600 \mathrm{mg} /$ day showed an average decrease in PBI of $\mathrm{I} .6 \mu \mathrm{g} / \mathrm{dl}$. Ten patients given chlorpromazine and other drugs showed significantly increased $T_{4}$ turnover ${ }^{229}$. Antithyroid activity has been suggested ${ }^{230}$.

(-) Chlorpropamide. Electrophoresis shows competition for TBG sites ${ }^{\mathbf{2 3 1}}$.

(O) Chorionic gonadotropin. No significant effect was found in a controlled study ${ }^{232}$.

(+) Clofibrate (Atromid S). Competes for sites in vitro on TBPA and TBA, but not $\mathrm{TBG}^{233}$. With doses of $2-2.5 \mathrm{~g}$ daily, the PBI increased from 5.9 to $7.4 \mu \mathrm{g} / \mathrm{dl}^{234}$. Others report no effect in vivo ${ }^{235}$.

(-) $0, p^{\prime}$-DDD. Competes with $\mathrm{T}_{4}$ for sites on $\mathrm{TBG}^{236}$.

(+) Dextrothyroxine (Choloxin). Although metabolically inactive, the dextro isomer is detected by all chemical tests ${ }^{211}$.

* Abbreviations used: $T_{3}$, tri-iodothyronine; $T_{4}$, thyroxine; $P B I$, protein-bound iodine; $C P B$, competitive protein binding; RAIU, radioactive iodine uptake; TBA, thyroxine-hinding alloumin: $\mathrm{TBG}$, thyroxine-binding globulin; TBPA, thyroxine-binding prealbumin. 
(O) Diazepam (Valium). No effect after in vivo administration ${ }^{237}$.

(-) Diazo dyes (Direct Blue, Evans Blue, Niagara Blue, Trypan Blue). Compete for $\mathrm{T}_{4}$ binding sites ${ }^{225},{ }^{238}$.

(O) Digitoxin. Given orally, o.oI $\mathrm{mg} / \mathrm{kg}$ per week, had no effect on $\mathrm{PBI}^{239}$.

(+) Di-iodohydroxyquin (Floraquin, Diodoquin). Absorbed through vaginal membrane. PBI increased $\mathrm{I}-4 \mu \mathrm{g} / \mathrm{dl}$ in half of patients ${ }^{240,241}$.

(-) 2,4-Dinitrophenol. Competes with $\mathrm{T}_{4}$ for sites on TBPA but not on TBG or TBA ${ }^{242}$. An antithyroid agent ${ }^{230}$.

(-) Diphenylhydantoin (Dilantin). Competes with $T_{4}$ for $T B G$ sites ${ }^{243}$ but not for TBA or TBPA. Increases metabolism of $T_{4}$ by the liver ${ }^{244,245}$.

(-) Disulfiram (Antabuse). Sulfide affects iodine assay. If not completely removed following ashing, sulfide complexes with ceric ion ${ }^{214}$.

$(+)$ Dithiazanine iodide (Delvex). PBI showed tendency to rise in 6 patients ${ }^{246}$.

$(+)$ Estrogens (oral contraceptives, pregnancy). Cause an increase in TBG, thus an increase in total $\mathrm{T}_{4}{ }^{24}$ ?

(+) Ether anesthetic. Probably a true change, mechanism unknown ${ }^{248}$.

(O) Fluoridated drinking water ${ }^{249}$.

(+) Gallamine triethiodide (Flaxedil) ${ }^{217}$.

(-) Gentisate. Competes with $\mathrm{T}_{4}$ for sites on TBPA but not $\mathrm{TBG}^{25}$.

(-) Gold sodium thiosulfate. Gold is bound to protein and excreted very slowly. Inhibits the ceric-arsenite reaction, probably by forming iodoauric acid. Gold is not removed in the dry ash step $\mathrm{p}^{\mathrm{s} !}$.

(?) Hydrochlorothiazide. One study found that the PBI was lowered, possibly due to a true change ${ }^{252}$. Another study found that the PBI was unchanged ${ }^{218}$.

$(+)$ Iodide (massive doses of potassium iodide). Excess inorganic iodine is removed if I4 washings, rather than 3 or 4 , are used. PBI may be elevated as a result of iodination of albumin or increased synthesis of di-iodotyrosine ${ }^{253-255}$.

(+) Iodinated albumin ${ }^{241}$. (Used for plasma volume determination.)

$(+)$ Iodinated drinking water. PBI is affected only at concentrations greater than $5 \mathrm{mg} /$ liter $^{256}$.

(+) Iodinated glycerol (Organidin). Doses of $125 \mathrm{mg} \mathrm{I} /$ day caused an average elevation of PBI by I.I $\mu \mathrm{g} / \mathrm{dl}$; of $200 \mathrm{mg} /$ day, by $2.0 \mu \mathrm{g} / \mathrm{dl}^{25}$.

$(+)$ Iodine-containing preparations. Included are topical applications such as antiseptics, oral disinfectants, antidandruff preparations, suntan preparations, and toothpastes; expectorants, antispasmodics, diuretics, and analgesics; intestinal disinfectants, including anthelminthics and amebicides; vitamin-mineral and cod liver oil preparations ${ }^{217}$.

$(+)$ Iodine, "occult". Ingestion of drugs whose iodine content has no pharmacologic function may remain undiscovered ${ }^{246,258}$.

(十) Iodochlorhydroxyquin (Vioform, Clioquinol). A metabolite is bound to protein. Eight subjects receiving $500 \mathrm{mg} /$ day showed a mean PBI of II $8 \mu \mathrm{g} / \mathrm{dl}^{226,259}$.

(O) Iodophor detergents (occupational exposure to atmospheric contamination by laundry workers). No effect on $\mathrm{PBI}^{\mathbf{2 6 0}}$.

$(+)$ Iothiouracil (Itrumil). Five patients receiving $200 \mathrm{mg} /$ day showed PBI values of $63^{-1} \mathrm{I} 9 \mu \mathrm{g} / \mathrm{dl}$. Thyroid function is depressed ${ }^{261}$.

(-) Isoniazid $+p$-aminosalicylate (Isopacin). Effect is due to the latter compound ${ }^{221}$.

(O) Isopropamide iodide (Darbid, Combid). No definite alteration in PBI ${ }^{246}$. 
(-) Mercurial diuretics (mercuhydrin, meralluride). Mercuric iodide is formed in the digestion and distillation procedures. No effect on dry ash procedure 218,262 .

$(+)$ Methysergide maleate (Deseril, Sansert). Mechanism unknown, probably a true change ${ }^{263}$.

(+) Metrecal. Ingestion of I quart per day led to increased PBI values in 6 subjects. Contains iodocasein ${ }^{264}$.

(O) Metronidazole. Daily dosage of $\mathrm{r} 200 \mathrm{mg}$ produced no change in one week ${ }^{\mathbf{2 6 5}}$.

(-) Penicillin. Competes for TBPA binding sites ${ }^{266}$.

$(+)$ Perphenazine. PBI levels greater than $8 \mu \mathrm{g} / \mathrm{dl}$ noted in $\mathbf{I} 3$ of 50 patients ${ }^{267}$. Iodinated contaminants may become strongly protein bound for some patients ${ }^{288}$.

(-) Phenylbutazone (Butazolidin). Probably competes for TBA sites. Has antithyroid activity ${ }^{222}$.

(+) Povidone-iodine (Betadine). PBI increased by $2.3 \mu \mathrm{g} / \mathrm{dl} 24 \mathrm{~h}$ after pre-operative treatment of vaginal tract ${ }^{269}$.

$(+)$ Pyrazinamide. Mechanism unknown ${ }^{270}$.

$(+)$ Radingraphic contrast media, iodine containing. These can be grouped according to the duration of the interference ${ }^{211,216,241,271}$.

Short (less than 6 weeks)

Bunamiodyl (Orabilex)

Diatrizoate (Hypaque)

Iodopyracet (Diodrast)

Intermediate (6-12 weeks)

Acetrizoate sodium (Urokon, Cystokon)

Iopanoic acid (Telepaque)

Long (more than is weeks)

Iodipamide (Biligrafin, Cholografin)

Iodized oil (Lipiodol)

Iodoalphionic acid (Priodax)

Iophendylate (Pantopaque)

Iophenoxic acid (Tcridax)

Propyliodone (Dionosil)

(O) Reserpine. No effect on PBI ${ }^{272}$.

(-) Salicylates. Compete for sites on TBPA but not on TBG or TBA ${ }^{211,242,273}$. Salicylates uncouple oxidative phosphorylation; there is true inhibition of thyroid activity indirectly via higher centers ${ }^{1,274-277}$. An early (I5-I20 min) decrease of $T_{4}$ levels results from increased free $T_{4}$ going to extra-hepatic regions ${ }^{278}$.

(+) Sulfobromophthalein (BSP). May be contaminated with organic iodine ${ }^{279}$.

(-) Sulfonamides. Some sulfonamides compete for binding sites $^{1}$.

(O) Tetracycline. No effect on PBI in I4 patients receiving $2 \mathrm{~g}$ daily for II days ${ }^{280}$.

(+) Tetraiodofluorescein (Erythrosine). (A pink dye used to color capsules, other medicines, foods, and lipsticks) ${ }^{281,282}$.

(O) Thiamylal (Surital). No effect on $\mathrm{PBI}^{248}$.

(-) Thiazide diuretics. Mechanism unknown; may involve a true change ${ }^{252}$.

(O) Thiopental (Pentothal, thiopentone). No effect on PBI ${ }^{218}$. Has marked antithyroid effect in rats ${ }^{283}$.

(O) Thioridazine (Mellaril). PBI remained unchanged in 6 women given $150 \mathrm{mg} /$ day for 60 days ${ }^{284}$. 
(-) Tolbutamide. Probably competes for binding sites ${ }^{\mathbf{2 3 1 , 2 8 5}}$.

(+) Tubing, plastic. One kind of tubing (Bard Intercath), used for intravenous infusions, contains an aliphatic iodine compound which is washed out and becomes protein-bound ${ }^{286}$.

(O) Warfarin. No effect at dnses of $5 \mathrm{mg} /$ day $^{287,288}$.

B. $T_{4}$-by-column. Serum is acidified with $\mathrm{pH} 4.0$ buffer to dissociate thyroxine $\left(\mathrm{T}_{4}\right)$ from serum proteins, added to an anion exchange column, and washed with acid to remove proteins, iodotyrosines, and certain exogenous iodinated compounds. Triiodothyronine $\left(T_{3}\right)$ and $T_{4}$ are quantitatively eluted with concentrated acetic acid; iodine is liberated either by alkaline incineration or by direct bromination, and determined by its catalytic effect on the ceric-arsenite reaction. Inorganic iodide remains on the columnn ${ }^{289,290}$. Significant drug interference occurs with substances which affect the amount of thyroxine in transport and with certain iodine-containing compounds. (-) Aminoglutethimide. Competes for $T_{4}$ binding sites ${ }^{1}$.

(-) Androgens, anabolic steroids. Decrease level of TBG, resulting in decreased total $\mathrm{T}_{4}{ }^{223}$.

(-) Barbiturates. Compete with $\mathrm{T}_{\mathbf{4}}$ for TBPA sites ${ }^{\mathbf{2 2 4}, \mathbf{2 2 5}}$.

(-) Chlorpropamide. Electrophoresis shows competition for TBG sites ${ }^{231}$.

(-) $0, p^{\prime}$-DDD. Competes with $\mathrm{T}_{4}$ for sites on $\mathrm{TBG}^{236}$.

$(+)$ Dextrothyroxine (Choloxin). Reacts as thyroxine ${ }^{211}$.

(O) Diazepam (Valium). No effect in vivo ${ }^{\mathbf{2 3 7}}$.

(-) Diazo dyes. Compete for $\mathrm{T}_{4}$ binding sites ${ }^{245,238}$.

(-) 2,4-Dinitrophenol. Competes with $T_{4}$ for sites on TBPA but not on TBG or TBA ${ }^{242}$. An antithyroid agent ${ }^{230}$.

(-) Diphenylhydantoin (Dilantin). Competes with $T_{4}$ for TBG sites ${ }^{243}$ but not for TBA or TBPA. Increases metabolism of $\mathrm{T}_{4}$ by the liver ${ }^{\mathbf{2 4 4}, \mathbf{2 4 5}}$.

$(+)$ Estrogens (oral contraceptives, pregnancy). Increase level of $\mathrm{TB}(\mathrm{x}$, resulting in increased total $\mathrm{T}_{4}{ }^{247}$.

(-) Gentisate. Competes with $\mathrm{T}_{4}$ for sites on TBPA but not $\mathrm{TBG}^{250}$.

$(+)$ Iodine, organic. Some exogenous organic iodine compounds clutc with thyroxine. Such cases are usually recognizable by abnormal elution patterns ${ }^{289}$.

$(+)$ Iodoalphionic acid (Priodax). Interferes when using direct bromination of the eluate $^{\mathbf{2 9 0}}$.

$(+)$ Iopanoic acid (Telepaque). Interferes when using direct bromination of the eluate $^{290}$.

(-) Iothiouracil (Itrumil). Thyroid function is depressed ${ }^{261}$.

(-) Oxyphenbutazone (Tandearil). We have observed yellow eluates from serum of patients receiving the drug. The color persists in the final reaction mixture.

(-) Penicillin. Competes for TBPA binding sites ${ }^{266}$.

(-) Phenylbutazone (Butazolidin). Probably competes for TBA sites. Has antithyroid activity ${ }^{222}$.

(-) Salicylates. Compete for sites on TBPA but not on TBG or TBA211,242,273.

(-) Sulfonamides. Some compete for binding sites ${ }^{1}$.

(-) Tolbutamide. Probably competes for binding sites ${ }^{231,285}$.

$C . T_{4}$ by competitive protein binding $(C P B)$. Ethanol is added to serum to precipitate proteins and extract the thyroxine. The alcohol extract is dried, and the residue is treated with a standard solution of normal serum in barbital buffer containing radio- 
iodine-labeled thyroxine. After equilibration, the unbound thyroxine is removed by gel filtration or by adsorption on ion exchange resin, and the bound radiothyroxine is counted. From the per cent bound radiothyroxine, the total unlabeled thyroxine is found using a standard curve ${ }^{211,292}$. Drugs which compete for binding sites act to decrease the total serum thyroxine level. If, however, the drug is extractable into ethanol, subsequent binding to TBG in the standard serum will increase the apparent $\mathrm{T}_{4}$ level in the unknown. (Barbital inhibits binding of $T_{4}$ to TBPA and the serum is diluted sufficiently in the method to minimize binding to TBA). CPB methods are considered to be more specific for thyroxine than either the PBI or $\mathrm{T}_{4}$-by-column test. (-) Androgens, anabolic steroids. Decrease level of TBG, resulting in a true decrease in total $\mathrm{T}_{\mathbf{4}}{ }^{223}$.

$( \pm)$ Chlorpropamide. Electrophoresis shows competition for TBG sites ${ }^{231}$. Tends to decrease total $\mathrm{T}_{4}$ but may be extracted by ethanol and cause false increase.

( \pm ) $0, p^{\prime}$-DDD. Competes with $T_{4}$ for sites on $\mathrm{TBG}^{236}$. Tends to decrease total $T_{4}$ but may be extracted by ethanol and cause false increase.

(t) Dextrothyroxine (Choloxin): Reacts as thyroxine ${ }^{211}$.

(-) 2,4-Dinitrophenol. Competes with $T_{4}$ for sites on TBPA but not on TBG or TBA ${ }^{242}$. An antithyroid agent ${ }^{230}$.

(+) Diphenylhydantoin (Dilantin). Competes with $T_{4}$ for TBG sites but is extracted from serum with ethanol and causes false increase in values ${ }^{243}$.

$(+)$ Estrogens (oral contraceptives, pregnancy). Increase level of TBG, resulting in a true increase in total $T_{4}^{247}$.

(-) Gentisate. Tends to decrease total $\mathbf{T}_{4}$ but does not bind to TBG ${ }^{250}$.

(-) Iothiouracil (Itrumil). Thyroid function is depressed ${ }^{261}$.

(-) Penicillin. Tends to decrease total $T_{4}$ by binding with TBPA but does not bind to $\mathrm{TBG}^{268}$.

(-) Phenylbutazone (Butazolidin). Probably tends to decrease total $T_{4}$ by binding to TBA. Has antithyroid activity ${ }^{222}$.

(-) Salicylates. Tend to decrease total $T_{4}$ by binding to TBPA, but do not bind to TBG $211,242,273$.

$D$. The $T_{3}$ test (unsaturated thyroxine-binding globulin). Serum is equilibrated with radioactive tri-iodothyronine $\left(\mathrm{T}_{z}\right)$ in the presence of a resin. The excess $\mathrm{T}_{3}$, adsorbed by the resin and counted, is inversely related to the concentration of unsaturated thyroxine-binding sites. In some methods the supernatant is counted and expressed as unsaturated thyroxine-binding capacity or index of normal. In the tabulation below, we express results as $T_{3}$-uptake by resin; thus, high $T_{3}$ values are found in hyperthyroidism and low $T_{3}$ values in hypothyroidism. Drug interferences include substances which produce an alteration in the total number of binding sites and drugs which compete with $T_{3}$ for the available sites. Factors affecting the $T_{3}$ test have been reviewed by Sisson ${ }^{293}$.

$(+)$ Aminoglutethimide. Competes for binding sites ${ }^{1}$.

(+) Androgens, anabolic steroids. Decrease level of TBG ${ }^{223}$.

(+) Barbiturates. Compete for TBPA sites ${ }^{224,225}$.

(+) Chlor propamide. Competes for TBG siles. $T_{3}$ resin results were increased proportional to level with in vitro addition and increased $10-30 \%$ with $30 \mathrm{mg} / \mathrm{kg}$ administered intravenously ${ }^{231}$.

(O) Clomiphene. Daily administration of $\mathrm{I00} \mathrm{mg}$ had no effect on the test ${ }^{294}$. 
$(+) o, p^{\prime}$-DDD. Competes for sites on $\mathrm{TBG}^{\mathbf{2 3} 6}$.

$(+)$ Dextrothyroxine (Choloxin). Binds to usual $\mathrm{T}_{4}$ binding sites, thus decreasing unsaturated $\mathrm{TBG}^{211}$.

(O) Diazepam (Valium). No effect after in vivo administration ${ }^{237}$.

(+) Diazo dyes. Compete for binding sites ${ }^{225,288}$.

$(+)$ Dicumarol and other coumarins. Compete with $T_{3}$ for TBA sites ${ }^{211,295}$.

(+) 2,4-Dinitrophenol. Competes for sites on TBPA ${ }^{242}$.

(+) Diphenylhydantoin (Dilantin). Competes for TBG sites but not for TBA or $\mathrm{TBPA}^{243}$. No effect was noted, however, after administration of $300 \mathrm{mg} /$ day for I week ${ }^{296}$.

(-) Estrogens (oral contraceptives, pregnancy). Increase levels of TBG ${ }^{247}$.

(+) Gentisate. Competes for sites on TBPA but not TBG ${ }^{250}$.

(+) Heparin. Competes with $T_{3}$ for TBA sites ${ }^{211}$. Also causes a transient significant elevation of free $\mathrm{T}_{4}{ }^{297}$.

(-) Iothiouracil (Itrumil). Thyroid function is depressed ${ }^{\mathbf{2 6 1}}$.

$(+)$ Ipodate (Uragrafin). A significant increase has been reported, which appears to be unrelated to iodine content 211,298 .

(O) Metronidazole. Daily dosage of $\mathrm{I} 200 \mathrm{mg}$ produced no change in one week ${ }^{265}$.

(+) Penicillin. Competes for TBPA sites ${ }^{266}$.

$(+)$ Phenylbutazone. Probably competes for TBA sites ${ }^{299}$.

(O) Povidone-iodine (Betadine) ${ }^{269}$.

(+) Salicylates. Compete for sites on TBPA, but not on TBG or TBA ${ }^{211}, 242,273$.

$(+)$ Sulfonamides. Some compete for binding sites'.

(O) Tetracycline. No effect on test in I4 patients receiving $2 \mathrm{~g} /$ day for II days ${ }^{280}$.

(O) Thiamylal (Surital). No effect on test ${ }^{248}$.

(O) Thiopental (Pentothal, thiopentone). No effect on test ${ }^{248}$.

$(+)$ Tolbutamide. $T_{3}$ resin results were increased proportional to level with in vitro addition and increased 5-10\% with I g administered intravenously $y^{231}$.

(Q) Warfarin. No effect at doses of $5 \mathrm{mg} /$ day $^{287,288}$.

E. Radioactive iodine uptake (RAIU). Radioactive iodide is administercd and, after the desired interval (usually $24 \mathrm{~h}$ ), thyroidal radioactivity is measured by an external scintillation counter and expressed as a percentage of a standard sample measured in an identical manner. Factors influencing the test have been reviewed by Grayson ${ }^{220}$ and by Magalotti et al. ${ }^{300}$. Interferences are produced by drugs which alter the size of the iodine pool, including iodinated organic compounds as well as inorganic iodine. The effect of iodinated organic compounds is related to metabolic processes which result in continual release of inorganic iodine such as occurs following administration of iodinated radiographic contrast media. Drugs which displace thyroxine from its carrier proteins, producing an increase in free thyroxine, can cause a temporary decrease in thyroidal uptake of iodine due to suppressed thyroxine synthesis.

(O) Acetazolamide. Drug produces no effect on test 218 .

(-) p-Aminobenzoate. Antithyroid activity has been suggested ${ }^{219}$.

(-) $p$-Aminosalicylate. Antithyroid activity has been suggested ${ }^{220-222}$.

(-) Barium sulfate. Sometimes contaminated with iodine sufficient to raise the PBI, hence could enlarge the total iodine pool ${ }^{212}$.

(-) Bromides. Some preparations contain iodide as a contaminant ${ }^{220}$.

(O) Calcium. Calcium loading and subsequent withdrawal had no effect in 7 subjects $^{228}$. 
(-) Chlorpheniramine (Chlor-Trimeton), antihistamine preparations. One 4-mg tablet 4 times/day reduced RAIU to $52 \%$ of original in 52 euthyroids ${ }^{300}$.

$(+)$ Chlorpromazine-procyclidine. Volunteers receiving the drugs in combination showed 24 -h RAIU of $39.7 \%$ compared to controls of $30.2 \%$. Renal iodine clearance $(2-3 \mathrm{~h})$ was decreased from 45.2 to $27.4 \mathrm{ml} / \mathrm{min}^{301}$.

(-) Clofibrate (Atromid S). Doses of $2-2.5 \mathrm{~g} /$ day resulted in decreased RAIU. The mechanism appears to be a displacement of $T_{4}$ bound to protein with transient increase in free $T_{4}$ and depression of thyroid function. The effect lasts $0.5-4$ months, after which pretreatment values are regained ${ }^{234}$.

(O) Diazepam (Valium). No effect after in vivo administration ${ }^{237}$.

(O) Digitoxin. Drug given orally, o.or $\mathrm{mg} / \mathrm{kg}$ per week, had no effect on RAIU ${ }^{239}$.

(-) Dithiazanine iodide (Delvex). RAIU depressed below normal range in 6 patients ${ }^{\mathbf{2 4}}$.

(O) Hydrochlorothiazide. No change in RAIU ${ }^{218,252}$.

(-) Indocyanine Green. Contains about $5 \%$ sodium iodide as a contaminant. Causes significant suppression, particularly for hyperthyroid individuals ${ }^{\mathbf{3 0 2}}$.

(-) Iodide (Massive doses of potassium iodide). Increases size of iodine pool.

(-) Iodinated drinking water. In concentrations of $\mathrm{I} \mathrm{mg} /$ liter (level used for disinfecting), RAIU is depressed ${ }^{256}$.

(-) Iodinated glycerol (Organidin). Daily dosage may contribute I25-200 mg iodine per day ${ }^{257}$.

(-) Iodine-containing preparations. See examples under PBI ${ }^{217}$.

(-) Iodine, inorganic. Preparations containing small doses reduce the thyroidal uptake without affecting the $\mathrm{PBI}^{246,303}$. Iodine and iodate, added to bread, may also cause individual or regional variations in $\mathrm{RAIU}^{304}$. Ingestion of drugs whose iodine content has no pharmacologic function may remain undiscovered ${ }^{258}$.

(-) Iodine, organic. Metabolism of organic iodine compounds may raise the plasma inorganic iodine level ${ }^{215}$. This category includes iodinated radiographic contrast media.

(-) Iothiouracil (Itrumil). Thyroid function is depressed ${ }^{261}$.

(-) Isoniazid $+p$-aminosalicylatc (Isopacin). Effect is duc to the latter compound ${ }^{221}$.

(-) Isopropamide iodide (Darbid, Combid). Significant decrease in RAIU in 8 of 9 subjects $^{246}$.

(O) Mercurial diuretics. No effect on 6 -h and 24 -h RAIU in 8 euthyroid subjects ${ }^{30 b}$. Another report suggests that diuretics given at the time of the test may depress uptake values whereas after prolonged diuresis the RAIU may be elevated ${ }^{300}$.

(-) Methantheline bromide (Banthine). Reported to decrease test results ${ }^{299}$.

(O) Metronidazole. Daily dosage of I200 $\mathrm{mg}$ produced no change in one week ${ }^{\mathbf{2 6 5}}$.

(-) Perphenazine. RAIU depressed ${ }^{306}$.

(-) Phenylbutazone. Has antithyroid activity ${ }^{222}$. In $\mathbf{I} 3$ euthyroid patients receiving $800 \mathrm{mg} /$ day for 4 days, the RAIU fell to $20-30 \%$ of control values ${ }^{307}$.

(-) Radiographic contrast media, iodine-containing. Metabolism raises the inorganic iodine pool. See list and duration of interference under PBI.

(O) Reserpine. No effect on RAIU'272.

(-) Resorcinol. Used in ointments and may be absorbed through the skin. Probably an antithyroid agent ${ }^{220}$.

(O) Salicylates. Test is not affected ${ }^{308}$.

(O) Tetracycline. No effect on RAIU in I4 patients receiving $2 \mathrm{~g} /$ day for II days ${ }^{280}$. 
(-) Vitamin A. Seven subjects were given 50000 IU orally per day for 2I-27 days. The 24 -h RAIU ranged from $21-68 \%$ before administration, and decreased to $\mathrm{I} 4-32 \%$ after administration, of the vitamin ${ }^{309}$.

TRANSAMINASF: (GOT)

Serum glutamic oxaloacetic transaminase (GOT) catalyzes transfer of an amino group from aspartate to $\alpha$-ketoglutarate with formation of oxaloacetate and glutamate. Oxaloacetate is measured colorimetrically after reaction with 2,4 -dinitrophenyl hydrazine or various azo dyes. For kinetic measurements, the reaction is coupled with NADH in the presence of malic dehydrogenase and the rate of disappearance of NADH is measured at $340 \mathrm{~nm}$. Except as noted, the following refer to results obtained with the current method on the Technicon SMA I2/60 in which oxaloacetate is dialyzed and reacted with Fast Ponceau L (diazotized $N$-butyl-4-methoxymetanilamide) according to Morgenstern et al ${ }^{310}$. The upper limit of normal is 40 units.

(+) Acetaminophen (APAP) ${ }^{11}$. Pure solution of the drug reported to produce color with the dye.

$(+)$ Acetoacetic acid ${ }^{311,312}$. Reacts with the dye to produce color and causes spurious elevation of GOT in paticnts with ketosis. $\Lambda$ cctone and $\beta$-hydroxybutyric acid do not react. A solution containing $8.3 \mathrm{mg} / \mathrm{dl}$ increased the apparent GOT by 38 units $^{313}$. No interference was encountered in the ultraviolet method nor with other coupling reagents tested ${ }^{312}$.

$(+) p$-Aminosalicylate ${ }^{.1}$. Pure solution of the drug reported to produce color with the dye.

(+) Ascorbic acid ${ }^{11}$. A solution containing $250 \mu \mathrm{g} / \mathrm{ml}$ produced color equivalent to 32 units. The usual concentration of ascorbic acid in serum is about $\mathrm{Io} \mu \mathrm{g} / \mathrm{ml}$ at which level interference would be negligible.

(+) Erythromycin ${ }^{314}$. Apparent GOT activity is elevated when either dinitrophenylhydrazine or a diazonium salt, azoene fast violet $B$, is used as color developer. The interfering substance is presumably a metabolite since erythromycin itself does not react. No interference was found with the ultraviolet kinetic method.

(+) Isoniazid ${ }^{\mathrm{i1}}$. A solution containing $3.2 \mu \mathrm{g} / \mathrm{ml}$ produced color equivalent to ro units.

(+) Levodopa ${ }^{11}$. A solution containing $20.8 \mathrm{\mu g} / \mathrm{ml}$ produced color equivalent to 33 units. With usual therapeutic doses, plasma levels rarely exceed $4 \mu \mathrm{g} / \mathrm{ml}$.

$(+)$ Methyldopa ${ }^{11}$. A solution containing $62.5 \mu \mathrm{g} / \mathrm{ml}$ produced color equivalent to I6 units. With usual therapeutic doses, plasma levels rarely exceed $3 \mu \mathrm{g} / \mathrm{ml}$ and interference should be negligible.

\section{UREA NITROGEN}

A. Reaction of uvea with diacetyl monoxime under acid conditions to produce a yellow color (Fearon reaction). Thiosemicabazide may be included in the reagent.

(-) Sodium azide ${ }^{315}$. May be added to serum as a preservative. At a concentration of roo $\mathrm{mg} / \mathrm{dl}$, serum urea was reduced from $5^{\circ}$ to an apparent $19 \mathrm{mg} / \mathrm{dl}$.

(t) Substituted ureas. Absorbance, relative to urea, has been reported as follows ${ }^{31 a}$ : Citrulline I.5

Hydantoin $\quad 0.3$ 
Methylurea I.5

Phenylurea 2.2

Sulfonylureas, and other compounds containing the ureido group, should also react ${ }^{317}$.

$B$. Serum is incubated with urease to relase ammonia from urea. Ammonia is then measured with the phenol-hypochlorite reaction. Phenol reagent must be added before hypochlorite; otherwise, deamination of various compounds can occur and lead to falsely elevated results, e.g., in the presence of uric acid, creatine, amino acids, and sulfanilamide ${ }^{318}$.

(-) Chloramphenicol.

(-) Streptomycin.

Both compounds are reported to inhibit color development ${ }^{319}$.

C. Incubation with urease to release ammonia followed by color development with Nessler's reagent.

(+) Acetone ${ }^{320}$. Turbidity is produced at levels frequently encountered in diabetic acidosis.

$(+)$ Chloral hydrate ${ }^{321}$. A rise of $4-6 \mathrm{mg} / \mathrm{dl}$ in apparent blood urea nitrogen values occurred go min after oral administration of $3 \mathrm{~g}$ of chloral hydrate.

$(+)$ Creatinine $^{\mathbf{3 2 0}}$. Elevated levels introduce a small positive error. Effect is minimized by reading absorbance at I min after Nesslerization.

$D$. Reaction of urea with dimethylaminobenzaldehyde in acidified ethanol to produce a yellow-green color.

$(+) p$-Aminosalicylate ${ }^{322}$. Produces similar color.

(+) Dextran ${ }^{323,324}$. Turbidity formation, owing to precipitation of dextran by ethanol.

$(+)$ Sulfonamides ${ }^{322,325}$. Produce similar color.

URIC ACID

Methods for the determination of uric acid have been reviewed recently by Martinek ${ }^{326}$. The enzymatic procedure of Liddle et $a l_{.}{ }^{327}$, is generally recognized as a suitable reference method.

A. Reduction of phosphotungstate by urate in alkaline solution to produce a blue color. Most of the following substances, or their metabolites, interfere as reducing agents.

(+) Ascorbic acid. In a carbonate-phosphotungstate method, I mg of ascorbic acid produced color equivalent to $\mathrm{I} .3 \mathrm{mg}$ of uric acid ${ }^{328}$. This interference can be eliminated by preliminary treatment of serum or protein-free filtrates with dilute alkali.

(+) Caffeine. Metabolites of caffeine and theophylline include methyl-substituted uric acids which act as reducing agents ${ }^{329,330}$. One $g$ of caffeine or theophylline per day increased the urinary non-urate chromogens from about $40 \mathrm{mg}$ (low purine diet) to $400 \mathrm{mg} /$ day. Concentrations of the metabolites in plasma are probably negligible.

(-) Chlorine. May be present as an impurity in distilled water. Forms hypochlorite which oxidizes urate in alkaline solution ${ }^{\mathbf{3 3 1}}$.

$(+)$ Ergothioneine. Present in red blood cells but not in plasma. Interferes if serum is hemolytic. 
(+) Gentisic acid. See salicylate.

(+) Glutathione. Present in red blood cells but not in plasma. Interferes if serum is hemolytic.

(+) Levodopa. When given in doses of $3-7 \mathrm{~g} /$ day, apparent serum uric acid was falsely elevated by an average of $20 \%$ and apparent urine uric acid was increased to 2-4 times the upper limit of normal. A dilute aqueous solution produced color in the reaction ${ }^{332}$. The ultraviolet method for uric acid was not affected.

(+) Methyldopa. With usual oral dosage, plasma concentrations are negligible $(2-3$ $\mu \mathrm{g} / \mathrm{ml}$ ) but urinary excretion may amount to $250 \mathrm{mg} / \mathrm{day}^{8}$. We have observed that an aqueous solution of $10 \mathrm{mg} / \mathrm{dl}$ produced a color equivalent to approximately Io $\mathrm{mg} / \mathrm{dl}$ of uric acid with the carbonate-phosphotungstate method.

$(+)$ Phenacetin ${ }^{11}$. Ingestion of $2 \mathrm{~g}$ of phenacetin or its metabolite, $N$-acetyl- $p$-aminophenol, increased apparent plasma uric acid by approximately $\mathrm{I} \mathrm{mg} / \mathrm{dl}$ after 2 to $4 \mathrm{~h}$. Apparent concentration of uric acid in urine was increased 2 -fold.

(t) Potassium ion. Produces turbidity with alkaline phosphotungstate. Plasma containing potassium salts of anticoagulants is unsuitable for uric acid determinations.

(+) Salicylate. Gentisic acid, a metabolite, acts as a reducing agent ${ }^{333}$. Relatively high concentrations appear in urine but not in plasma. However, high concentrations of uricase-resistant chromogens have been noted in serum from patients with gout whose serum salicylate was maintained near $30 \mathrm{mg} / \mathrm{dl}^{394}$.

$(+)$ Theophylline. See caffeine.

$B$. Methods depending on action of uricase.

(士) Formaldehyde (formalin). Inhibits uricase activity ${ }^{335}$. Leads to low results if formalin is added as a preservative to specimens. False high results may be obtained if unknowns are compared to standards containing formalin.

UROBILINOGEN (URINE)

Urobilinogen reacts with $p$-dimethylaminobenzaldehyde in acid solution (Ehrlich's aldehyde reagent) to produce a red color. Sodium acetate is added to reduce acidity, to intensify the color, and to inhibit color formation from indole. Porphobilinogen also reacts but will remain in the aqueous layer, in contrast to urobilinogen, after extraction with chloroform ${ }^{336}$. An additional extraction with butanol is claimed to remove all of the known Ehrlich aldehyde compounds, except porphobilinogen, and forms the basis of a highly specific test for the latter ${ }^{337}$.

(+) $p$-Aminosalicylate ${ }^{338}$. Urine from patients receiving this drug produces a red color with the reagent.

(t) Bilinubin. Forms a green color under the reaction conditions and should be removed by treating the urine with barium chloride prior to performing the test.

(+) Chlorophyll ${ }^{339}$. A metabolite, phylloerythrinogen, forms a dark red condensation product with the reagent.

(t) Chlorpromazine ${ }^{340}$. May lead to increased values for urobilinogen, in the absence of jaundice.

(+) 5-Hydroxyindoleacetic acid ${ }^{336,341}$. Produces a bluish-pink color with the reagent.

(十) Indole ${ }^{341}$. Present in normal urine and produces an orange-brown color with the

Clin. Chim. Acta, 4I (1972) 395-434 
reagent. Interference is minimized by adding acetate immediately after mixing urine with the reagent.

$(+)$ Phenazopyridine (Pyridium) ${ }^{9}$. Colors urine orange-brown and becomes reddishbrown in acid solution.

(+) Radiographic contrast media. Diatrizoate (Hypaque) produces a heavy yellow precipitate with the reagent ${ }^{208}$ and iopanoic acid (Telepaque), a white cloudy precipitate ${ }^{342}$. Both compounds are precipitated in acid solution.

(-) Smog ${ }^{343}$. Spots on paper chromatograms are reported to be destroyed, presumably due to oxidation by ozone.

$(+)$ Sulfonamides ${ }^{336,388,341}$. Those containing a free amino group produce a greenishyellow color with the reagent.

VANILMANDELIC ACID (VMA)

A. Screening tests on wrine are based on the reaction with diazotized p-nitroaniline to produce a purple color which is extracted into $n$-amyl alcohol ${ }^{344}$. Such methods lack specificity and results can be misleading. More elaborate extraction and purification are claimed to improve specificity ${ }^{345}$.

(t) $p$-Aminosalicylic acid. Produces color with diazo rcagent ${ }^{346}$.

(+) Anileridine ${ }^{347}$.

(+) Bananas. Apparent elevation owing to increased excretion of 5-HIAA (see below).

(+) 5-Hydroxyindoleacetic acid ${ }^{348}$. Elevation in apparent VMA is directly proportional to the concentration of 5-HIAA.

(+) Methenamine mandelate (Mandelamine) ${ }^{\mathrm{I}}$. Reported to produce a similar color.

(t) Methocarbamol ${ }^{347}$.

(+) Phenolsulfonphthalein (PSP). Can result in color if not completely extracted ${ }^{346}$. $B$. Quantilative procedure of $P$ isano, based on extraction, purification, oxidation to vanillin, and measurement of absorbance at $360 \mathrm{~nm}^{349}$.

(-) Clofibrate ${ }^{350}$. The glucuronide moiety of the excreted conjugate competes for periodate in the oxidation step. This can be overcome by increasing the concentrations of periodate and metabisulfite 5 -fold.

(O) Methyldopa ${ }^{351}$. No interference was observed in Pisano's method.

(t) Nalidixic acid ${ }^{302}$. The free acid shows significant absorbance at $360 \mathrm{~nm}$. Apparent urinary excretion of VMA may be increased up to 4 -fold on usual therapeutic regimens.

(O) Vanillin ${ }^{353}$. Dietary vanillin, up to $62 \mathrm{mg} /$ day, was shown to have no effect on VMA values obtained by Pisano's method.

\section{INDEX OF METHODS}

$\begin{array}{ll}397 & \text { Amylase } \\ 397 & \text { Barbiturates } \\ 398 & \text { Bilirubin } \\ 399 & \text { Blood, occult } \\ 399 & \text { BSP test } \\ 400 & \text { Calcium } \\ 401 & \text { Catecholamines } \\ 401 & \text { Chloride } \\ 402 & \text { Cholesterol } \\ 403 & \text { Cortisol, plasma }\end{array}$


403 Creatinine

404 Estrogens

404 Glucose

407 Homovanillic acid

407 I 7 -Hydroxycorticosteroids

408 5-Hydroxyindoleacetic acid

$4 \mathbf{I}_{7}$ Iodine uptake. See thyroid function lests.

408 Ketone bodies (urine)

$409 \quad$ r 7 -Ketosteroids and 17 -Ketogenic steroids

4II Lactic dehydrogenase

4I I Lipase

4I I Magnesium

4OI. Metanephrines. See catecholamines.

4I I Phosphatase, alkaline

412 Phosphate

4I2 Porphyrins

412 Pregnancy tests

4I3 Protein

4I 7 Protein-bound iodine. See thyroid function tests.

4.5 Prothrombin time

4I6 PSP test

4I6 Specific gravity (urine)

$4 I 7 \quad T_{3}$ and $T_{4}$ tests. See thyroid function tests.

4I 6 Thymol turbidity

4I7 Thyroid function tests

417 Protein-bound iodine

$420 \quad T_{4}$-by-column

$420 \quad \mathrm{~T}_{4}$ by CPB

$42 \mathrm{I} \quad \mathrm{T}_{3}$ test

422 Radioactive iodine uptake

424 Transaminase

424 Urea nitrogen

42.5 Uric acid

426 Urobilinogen

427 Vanilmandelic acid

\section{REFERENCES}

I M. Lubran, Med. Clin. N. Amer., 53 (I969) 2 I I.

2 D. C. Cilristian, Amer. J. Clin. Pathol., 54 (1970) I 8.

3 F. W. Sunderman, Jr., Crit. Rev. Clin. Lab. Sci., I (1970) 427.

4 M. P. Eliking ANd H. F. Kabat, Amer. J. Hosp. Pharm., 25 (I968) 485.

$5 \mathrm{~S}$. GARB, Clinical Guide to Undesivable Drug Interactions and Interferences, Springer, New York, I97I.

6 E. W. Martin, Hazards of Medication, Lippincott, Philadelphia, I971, pp. I69-2r 5.

7 P. D. Hansten, Drug Interactions, Lea \& Febiger, Philadelphia, I97I.

8 A. Sjoerdsma, A. Vendsalu and K. Engelman, Circulation, 28 (I963) 492.

9 H. N. Naumann, Amer. J. Cilin. Pathol., 48 (I967) 337.

io R. T. O’Kell, D. F. Knepper, B. D. Spoon and J. R. Elliott, Clin. Chem., i 7 (I971) 352.

I I H. P. Singh, M. A. Hebert and M. H. Gault, Clin. Chem., r8 (1972) I37.

i 2 H. J. Van Peenen and J. B. Files, Amer. J. Clin. Pathol., 52 (I969) 666.

13 P. E. Cryer and J. Sode, Ann. Internal Med., 75 (I97I) 697.

I 4 S. Borushek and J. J. Gold, Clin. Chem., io (I964) 4 I.

I 5 E. K. Kastrup and G. H. Schwach, Facts and Comparisons, $4^{\text {th }}$ ed., Facts and Comparisons, Inc., St. Louis, I963.

i6 R. L. McGeachin, H. K. Daugherty, L. A. Margan and B. A. Potter, Clin. Chim. Acta, 2 (I957) 75 .

I7 S. F. Penaranda, Ann. Biol. Clin. (Paris), ig (I96r) 3 I9.

I 8 E. Z. HeLMan, Clin. Chem., i6 (I970) 797 .

I9 D. M. Baer, Amer. J. Clin. Pathol., 44 (I965) I I4.

20 M. Marcus and S. KletnberG, Clin. Chem., i 8 (1972) 492.

2 I R. Guzak and W. T. Caraway, Amer. J. Med. Technol., 29 (1963) 23I.

22 L. V. Crowley, Amor. J. Clin. Pathol., 5 (1969) 425. 
23 S. Meites and C. K. HogG, Clin. Chem., 5 (1959) 470.

24 R. J. Henry, O. J. Golub, S. Berkman and M. Segalove, Amer. J. Clin. Pathol. 23 (1953) $84 \mathrm{I}$.

25 L.S. Goodman and A. Gilman, The Pharmacological Basis of Therapeutics, 4 th ed., Macmillan, New York, I97o, p. I292.

26 G. V. Irons, Jr. And J. B. Kirsner, Amer. J. Med. Sci., 249 (I965) 247.

27 G. H. M. ThORnTON AND D. G. ILlingWORTH, Gusiroenleyulogy, z8 (1955) 593.

28 J. B. CARDWELL, Lancet, ii (r969) 326.

29 J. B. Earnest, H. L. Fred and J. M. Eiband, Brit. Med. J., ii (r966) 703.

30 L. J. Schoenfield and W. T. Foulk, J. Clin. Invest., 43 (r964) I4I9.

3 i G. H. Mlarguardt, C. 1. Fisher, F. Levy and R. M. Dowben, J. Amer. Med. Assoc., i75 (I96I) $85 \mathrm{I}$.

32 R. R. Meyer, J. Amer. Med. Assoc., I94 (1965) 343.

33 D. Shotton, M. Carpenter and W. B. RineharT, New Engl. J. Med., 264 (I96T) 550 .

34 R. G. Martinek, J. Amer. Med. Technol., 33 (r97I) 4 r6.

35 R. E. Mosher, M. Itano, A. J. Boyle, G. B. Myers and L. T. Iseri, Amer. J. Clin. Pathol., 2I (I95I) 75 .

36 V. Kapuscinski, N. Moss, B. Zax and A. J. Boyle, Amer. J. Clin. Pathol., 22 (I952) 687.

37 G. L. Baker and L. H. Johnson, Anal. Chem., 26 (I954) 465 .

38 P. S. Chen, Jr. and T. Y. Toribara, A nal. Chem., 25 (I953) I642.

39 A. Zettner and D. Seligson, Clin. Chem., io (1964) 869.

40 M. H. CARR ANd H. A. Frantz, Clin. Chem., 3 (r957) 20.

4I N. W. Tietz, in N. W. Tretz (Ed.), Fundamentals of Clinical Chemistry, Saunders, Philadelphia, I970, p. $64 \mathrm{I}$.

42 M. MAGER And G. Farese, Clin. Chem., I 2 (1966) 234.

43 B. N. Bachra, A. Dauer ANd A. E. Sobet, Clin. Chern., $4(1958)$ ro7.

44 E. S. Buckley, Jr., J. (x. Gibson II and T. R. Bortolottr, J. Lab. Clin. Med., 38 (I951) 75 I.

45 A. D. Kenny and S. U. Toverud, Anal. Chem., 26 (I954) Io59.

46 D. Hingerty, Lancet, i (1957) 766.

47 J. R. CRout, in D. SeLIGson (Ed.), Standard Methods of Clinical Chemistry, Vol. 3, Academic Press, New York, I96I, pp. 62-8o.

48 D. W. Neill, I. J. Carré, R. L. McCorry and R. H. Thompson, J.Clin. Pathol., I4 (I96I) 4 I 5.

49 M. O. Klotz, H. Richter and M. Meuffels, Clin. Chem., io (I964) 372.

50 J. D. Saptra, T. Klaniecki and G. Ratkin, $J$. Amer. Med. A ssoc., 212 (r970) 2243.

5 I R. W. Gifford and D. C. Tweed, J. Amer. Med. Assoc., I82 (I962) 493.

52 S. M. Sax, H. E. Waxman, J. H. Aarons and H. J. Lynch, Clin. Chem, 6 (r960) i68.

53 J. J. Pisano, Clin. Chim. Acta, 5 (Ig6o) 406.

54 A. G. Blumberg, A. M. Heaton and I. Vassilyades, Clin. Chem., I2 (Ig66) 803.

55 L. R. Johnson, M. Reese And D. H. Nelson, Clin. Chem., I 8 (1972) 209.

56 R. S. Blume, J. D. Maclowry and S. M. Wolff, New Engl. J. Med., 279 (1968) 593.

57 J. L. Driscoll aND H. F. MARTIN, Clin. Chem., I2 (I966) 314.

58 D. B. Tonks, Clin. Biochem., I (1967) I2.

59 R. G. Martine K, J. Amer. Med. Technol., 32 (1970) 64.

60 T. C. Huang, C. P. Chen, V. Wefler and A. Raftery, Anal. Chem., 33 (I96I) I 405.

gi A. T. Ness, J. V. Pastewka ant A. C. Peacock, Clin. Chim. Aclu, io (ig64) 229.

62 L. L. Abell, B. B. Levy, B. B. Brodie and F. E. Kendali, in D. Seligson (Ed.), Standard Methods of Clinical Chemistry, Vol. 2, Academic Press, New York, 1958, pp. 26-33.

63 A. Zlatkis, B. ZAK and A. J. Boxle, J. Lab. Clin. Med., 4 I (I953) 486.

64 H. H. LefFler, Amer. J. Clin. Pathol., 3I (I959) 3 ro.

65 H. H. Leffrler and C. H. McDovgald, Amer. J. Clin. Pathol., 39 (I963) $3 \mathrm{Ir}$,

66 R. J. Franey and E. Amador, Clin. Chim. Acta, 2i (Ig68) 255.

67 E. W. Rice and D. B. Lukasiewicz, Clin. Chem., 3 (I957) I6o.

68 E. B. Solow and L. W. Freeman, Clin. Chem., 16 (1970) 472.

69 E. W. Rice, Clin. Chim. Acta, I4 (I966) 278.

70 E. W. RICE, Clin. Chem., IO (1964) IO25.

7 I A. Mrskos ann J. TovareK, Arch. Biochem. Biophys, gI (r96o) I52.

72 R. J. Henry, Clinical Chemistry: Principles and Technics, Hoeber, New York, I964, p. 861.

73 L. J. Kinley and R. F. Krause, Proc. Soc. Exp. Biol. Med., 99 (I958) 244.

74 B. Z $\mathrm{AK}_{\mathrm{K}}$, in S. MEITES (Ed.), Standard Methods of Clinical Chemistry, Vol. 5, Academic Press, New York, 1965, pp. 79-89.

75 E. E. Werk, JR., K. E. Theiss, Y. K. Chot and R. T. Marneld, J. Clin. Endocrinol. Metab., 27 (1967) I.350.

76 J. W. Kendall, M. L. Egans and A. K. Stott, J. Clin. Endocrinol. Metab., 28 (1968) 1373. 77 A. O. Lurie, J. Amev. Med. Assoc., 2 I I ( 1970 ) I 85 I. 
78 D. I. Fabriny and G. Ertmangshausen, Clin. Chem., i 7 (1971) 696.

79 H. H. Taussky, in D. Seligson (Ed.), Standard Methods of Clinital Chenistry, Vol. 3, Academic Press, New Xork, I96I, pp. 99-xi3.

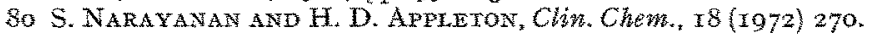

$8 \mathrm{I}$ R. W. Bonshes AND H. H. TAUssky. J. Biot. Chem., I 58 (r945) $58 \mathrm{r}$.

82 H. N. HAUGEN, Scand. J. Clin. Lab. Invest., $6(\mathrm{r} 954)$ I 7 .

83 R. S. Hare, Proc. Soc. Exp. Biol. Med., $74(\mathrm{r} 950) \mathrm{r}_{4} 8$.

84 H. H. Taussky, J. Biol. Chem., 208 (I954) 853 .

85 M. Paget, M. Gontier and J. Liefooghe, Ann. Biol. Clin. (Paris), 13 (r955) 535.

86 J. A. BARCLAY AND R. A. KENNEY, Biochem. J., 4T (r947) 586 .

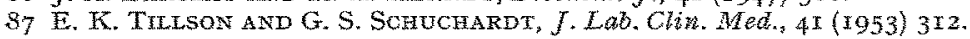

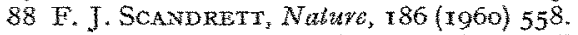

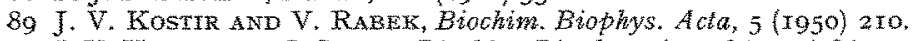

90 J. V. Kostir AND J. SoNkA, Biochim. Biophys. Acta, 8 (1952) 86 .

9 H. H. TAUssky, Clin. Chm. Acta, I (I956) 2 xo.

92 J. B. Brown, Biochem. J., 60 (I955) I85.

93 J. B. BRown, R. D. BULBRoOK AND F. C. GreEnwood, J. Endocrinol., I6 (1957) 49.

94 A. F. Rosentual and M. R. Tomson, Clin. Chem. $18(1972) 47 \mathrm{x}$.

95 J. P. COMER, Amat. Chem., 28 (r956) 1748.

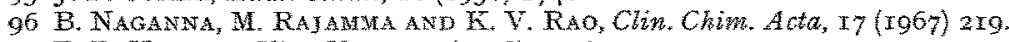

97 F. E. HolmEs, Chin. Chemb. $14(1968)$ I 136 .

98 J. M. Fecdman and H. E. Lebovitz, New Engl. J. Med., 283 (1970) ro53.

99 J. M. Feldman, W. N. Kelly and H. E. Lebovitz, Diabetes, 19 (r970) 337

ioo M. S. Zileli, F. Teletar, S. Deniz, E. Tliter and N. Adal f, J. Amer. Med, Assoc, 215 (1971) 1986 .

ror K. A. B. KRISTENSEN, New Engl. J. Med., 283 (r97o) 660 .

I02 K. M. Dubowski, Chim. Chem., 8 (Ig62) $2 \times 5$.

103 W. T. CARAWAY, Clin. ChBm. I7 (T971) 63.

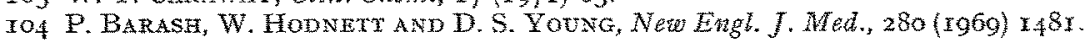

I05 C. S. Frings, Clin. Chem., 6 (1970) 618 .

Io6 D. WATSON, Clin. Chim. Acta, 7 (I962) 145.

107 M. ENkLewitz, J. Phamacol. Exp. Therap., 54 (1935) 100.

Io8 S. L. TOMPSET, Biochem., $f ., 24$ (I930) II 48.

Iog R. E. Strange, F. A. DARK AND A. G. NESs, Biocheth. I., 59 (1955) r72.

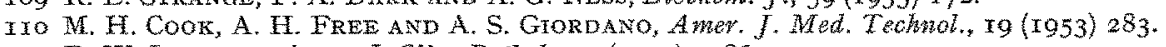

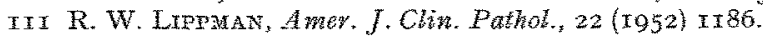

II R. D. LEAs, J. Lab. Clin. Med. r2 (1926) I5.

I 3 I. Iuchi AND S. Smbata, Clm. Chim. A gla, 5 (ro6o) 42 .

II G. J. Fashena and H. A. STtFF, J. Biol. Chem, r37 (194t) 2 r.

x 5 S. E. Mrcler, A Textbook of Clinical Pathology, 7 th ed., Willams \& Wilkins, Baltimore, r966, p. 370 .

116 T. G. KLUnep, $f$. Amer. Math. Assoc., 193 (1965) 746.

Ix R. L. Whrpple, JR. AND W.L. Bioom, J. Lab. Clin. Med., 36 (x950) 635.

I8 S. LFe AND I. SCHoEN, New Engl. J. Med., 275 (Tg60) 266 .

II9 D. W. VolK, A. SAIFER AND S. S. LAZARUS, J Lab. Chin. Wed., 57 (196r) 367 .

Izo H. W. Nevierg, Amer. J. Clin. Paihol, $24(1954) 245$.

I2I W. R. Todd, M. C. Dodson, J. B. Trainje AND J. McKeE, Arch. Biochem., 4 (I944) 337.

I22 R. Hoelotke, Amer. J. Clin. Pathol., 57 (r972) 324.

I23 C. C. PORTER AND R. H. SILBer, J. Biol. Chem., t85 (1950) 201.

I24 R. H. SILBER anD C. C. PORTER, J. Biol. Chewn, zTo (I954) 923.

I25 F. W. SUNDERMAN, JR., in I. W. SUNDERMAN AND F. W. SUNDERMAN, JR. (Eds.), Lipids ahd

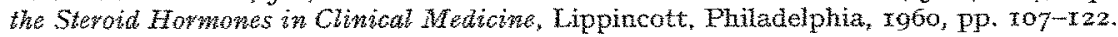

126 A. LupovireH, Chn. Chent. 1 (1968) 179 .

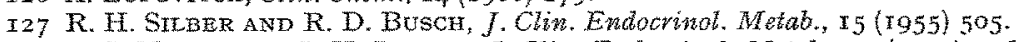

I28 L. S. MARks and J. H. Leftin, $J$. Clin. Endocrinol. Metab., T4 (I954) T263.

I29 L. E. Braverman, H. Rernstern, H. LoAxzA AND D. POMrret, Clin. Chem., I4 (x968) 374.

izo R. S. Strempel, JR, J. B. Sidbury, JR. ANio C. J. Migeon, J. Clin. Endocrinol. Metab., 20 (1960) $8 \mathrm{r} 4$.

I3I P. C. Desper, E. B. Funk AND J. E. JONES, Metabohism, I 5 (1966) 823 .

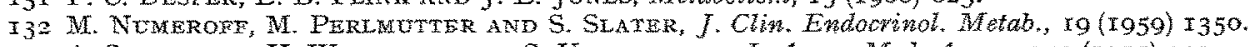

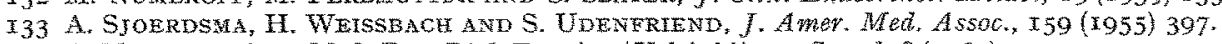

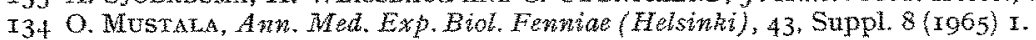

r35 J. R. Crout and A. Sroerosma, Newe Ekgi. J. Med., 261 (1959) 23.

I36 M. E. Skrts, Clin. Chem., I $3($ r967) 397 . 
i37 A. T. Pedersen, J. G. Batsakis, N. A. Vanselow and J. A. Mclean, J. Amer. Med. Assoc., 2 I I (I970) TI 84 .

I38 S. UdENFRIEND, E. TiTus AND H. Weissbach, J. Biol. Chem., 216 (.1955) 499.

I39 J. C. Honet, T. V. Casey and J. W. Runyan, JR., New Engl., J. Med., 26 i (I959) I88.

I 40 G. Ross, B. WeINSTEIN AND B. KaBakow, Clin. Chem., 4 (I958) 66.

I I O. O. Mústala, J. J. Tuomisto and M. M. Airaksinen, Scand. J. Clin. Lab. Invest., I6 (I964) 655 .

I 42 N. K. Gibbs AND L. I. Woolf, Brit. Med. J., ii (I959) 532.

I 43 H. Riekers and J. B. Miale, Amer. J. Clin. Pathol., 30 (I958) 530.

i 14 H. M. Free, R. R. Smeby, M. H. Cook and A. H. Free, Clin. Chem., 4 (1958) 323.

I45 R. Pocelinko, H. M. Solomon and Z. N. Gaur, New Engl. J. Med., 281 (r969) Io75.

I 46 M. J. Cawein, M. A. Williamson, C. Ebenezer and J. P. Hewins, New Engl. J. Med., 283 (I970) 659

I 47 J. W. Hadden and R. J. Metzner, Amer. J. Med., 47 (I969) 642.

I 48 G. J. Wolcott and T. N. HAckett, JR.; Lancet, ii (I969) I 20 I.

I 49 C. Sobel, O. J. Golub, R. J. Henry, S. L. Jacobs and G. K. Basu, J. Clin. Endocrinol. Metab., I8 (1958) 208.

I 50 A. F. HoltorfF AND F. C. Koch, J. Biol. Chem., r35 (I940) 377 .

I5 C. H. Gray, D. N. Baron, R. V. Brooks and V. H. T. James, Lancet, i (I969) I 24.

I52 M. G. Metcalf, Clin. Biochem., $i$ (I967) I 72.

I53 S. Salvesen and R. Nissen-Meyer, J. Clin. Endocrinol. Metab., I7 (1957) 914.

I54 S. SALVESEN AND R. NISSEN-MEYer, Acta Endocrinol., 29 (r958) 224.

I55 O. Llerena and O. H. Pearson, New Engl. J. Med., 279 (I968) 983.

I56 B. F. Bower, R. McComb and M. Ruderman, New Engl. J. Med., 277 (I967) 530.

I57 V. R. Mattox, R. V. Rant)alt and J. Goodrich, Metabolism, I6 (I967) 752.

I 58 J. C. Nelson, G. G. Krueger, R. B. Wilcox and W. P. Thompson, J. Clin. Endocrinol. Metab., 28 (I968) I5I5.

I59 L. N. Antunes, J. Clin. Endocrinol. Metab., I6 (I956) I 125.

I6o R. E. Megraw, Amer. J. Clin. Pathol., 56 (I97I) 225.

I6I W. C. Voget ANd L. Zieve, Clin. Chem., 9 (r963) r68.

r62 L. ZIEve AND W. M. DoIZAKI, J. Lab. Clin. Med., 67 (I966) I 27.

r63 C. S. ANAST, Clin. Chem., 9 (1963) 544.

I6. C. J. Bark, Amer. J. Clin. Pathol., 52 (1969) 466

i65 J. A. Mackie, Jr., D. A. Arvan, J. L. Mullen, Jr. and H. M. Rawnsley, Amer. J. Suvg., I2I (I97I) 57 .

I66 J. H. SChIFFNER, New Engl. J. Med., 282 (I970) 63I.

I67 P. H. Henneman, G. M. Rourke and W. P. U. Jackson, J. Biol. Chem., 213 (I955) I9.

I68 B. Castleman and B. U. McNeely, New Engl. J. Med., 276 (I967) I67.

I69 H. J. VReman and F. F. Jöbsis, Anal. Biochem., i7 (I966) Io8.

I70 B. S. Cook and D. H. Simmons, J. T.ab. Clim. Med., 60 (т962) т60.

I7I J. McEwen and C. Paterson, Brit. Med. J., i (I972) 42 I.

172 G. H. Hilbert, Amev. J. Clin. Pathol., 3 I (I959) 466.

i73 F. Paoletti, A. Juan, J. Vazquez and P. L. Wolf, Amer. J. Med. Sci., 252 (Ig66) 570.

r4 R. Ravel, II. G. Rieners and B. J. Goldstein, Amer. J. Obstet. Gynecol., Io5 (I969) I222.

I 75 G. Fine, A. R. Morales and R. C. Horn, Jr., Amer. J. Clin. Pathol,, 49 (I968) I7I.

I 76 V. Marks and P. Shackcloth, Brit. Med. J., i (Ig66) 5 I 7 .

r 77 F. G. SUlman AND H. Z. WinNiK, Lancet, i (I956) I6I.

I 78 M. C. KEw, H. C. SEFTEL AND B. M. Bloomberg, Lancet, i (I967) 902.

I79 A. K. N. WARRACK AND H. RICHARDS, Lancet, i (r967) 957.

I80 J. L. BeLL, Lancet, ii (I967) 559.

I8r W. ROHDE AND G. DÖRNER, Lancet, ii (I967) 372.

r82 J. J. MoORE AND S. M. SAX, Clin. Chem., I 8 (I972) 393.

183 R. J. Henry, Clinical Chemistry: Principles and Technics, Hoeber, New York, I964, p. 185.

I 84 G. R. KingSLEY, J. Biol. Chem., I3I (I939) 197.

185 D. A. ARVAN and A. Ritz, Clin. Chim. Acta, 26 (1969) 505

I 86 D. Dow and P. V. C. PinTo, Clin. Chem., I5 (1969) Ioo6.

I 87 M. M. Niall and J. A. Owen, Proc. Assoc. Clin. Biochem., i (Ig6r) I3o.

I 88 H. Kutt and F. McDowell, J. Lab. Clin. Med., 59 (r962) i I 8.

I 89 D. A. Arvan, B. S. Blumberg and L. Melartin, Cline. Chim. Acta, 22 (1968) 2 I I.

igo R. J. Henry, C. Sobel and M. Segalove, Proc. Soc. Exp. Biol. Med., 92 (I956) 748.

I9I C. A. Pennock, I. P. Passant and F. G. Bolton, J. Clin. Pathol., 2 I (i968) 5 I8.

I92 H. A. Zondag and G. L. van Boetzelaer, Clin. Chim. Acta, 5 (I960) I 55 .

I93 O. SvensmaRk, Scand. J. Clin. Lab. Invest., ro (1958) 50.

194 H. P. RIEDER, Clin. Chim. Acta, 6 (I96I) I 88. 
195 E. T. OpStad, Minnesola Med., 4I (x958) II I.

ig6 M. Levy and M. Eliamim, $J$. Amer. Med. Assoc, zrg (r972) 908.

I97 J. E. Holoubek, W. H. Carroll, G. M. Riley and R. B. Langrord, J. Amen. Med. Assoc., 153 (T953) ror 8.

198 T. J. McMrLcri, Northyest Med. 55 (1956) 30 I.

199 E. E. Seedore, W. N. Powell, R. G. Greenlez and D. N. Dysart, Radiology, $59(1952) 422$.

200 E. E. Seedorf, W. N. Powell, R. G. Greenle and D. N. Dysart, J. Amer. Med. Assoc., I 52 (I953) I 332.

201 A. H. FreE, C. O. Rupe ANd I. Metzler, Clin. Chem., 3 (I957) 716.

202 C. R. ARNoLd AND R. W. LANENER, Brit. Med. J., i (1963) $52 \mathrm{I}$.

203 A. H. FREe AND O. E. FANCHer, Amer. J. Med. Technol, 24 (r958) 64.

204 I. T. Sigeli and H. C. Flessa, J. Amer. Med. Assoc. $214(1970) 2035$.

205 J. Koch-Weser and E. M. Sellers, New Engl. J. Med., 285 (r97 I) 487. 547.

206 M. F. Kossover, M. E. Beckham and S. A. Threefoor, Amer.J. Med. Sci., 247 (1964) 694.

207 J. K. HEALY, K. D. G. EDWARDS AND H. M. WhYTe, J. Clin. Pathol, r7 (r964) 557.

208 R. HuRT, Amer. J. Med. Technol., 26 (1960) 122.

209 K. Albertsen and F. Heintzelmank, Acta Med. Scand., 136 (1950) 316.

2 Io Z. Horn and E. Kovacs, Acta Med. Scand., r64 (1959) r43.

zir S. Berger, in N. W. Tterz (Ed.), Fundamentals of Clinical Chemistry, Saunders, Philadelphia. r97o, pp. $587-6$ r.

2 I2 R. L. Rapport and G. M. CtrTIS, J. Clin. Endocrinol., ro (1950) 735.

2r3 K. LIEWENDAHL, Scand. J. Clin. Lab. Invest., 23 (1969) 185.

$2 \mathrm{I}$ S. B. Barker, M. J. Humphrey aNd M. H. SoleY, J. Clin. Invest., 30 (I951) 55 .

2 I 5 A. L. Chanex, Advan. Clin. Chem, x (x958) 8I.

2 I6 P. J. Davis, Amer. J. Med., 40 (1966) 918.

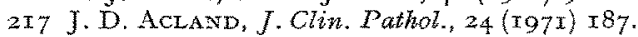

218 D. E. Schteingart, M. Perlmutter and M. Numeroff, Amer. J. Med. Sci., $239(1960) 571$.

2 I9 D. M. FawCetT and S. Kirkwood, f. Biol. Chem., 204 (1953) 787.

220 R. R. Grayson, Amer. J. Med., 28 (rg6o) 397.

$22 \mathrm{r}$ E. SeInfeld and P. Starr, Amer. Rew. Respirat. Diseases, 80 (1959) 845.

222 S. H. INGaA AND K. A. Woeber, in R. H. Wullams (Ed.), Textbook of Endocrinology, 4 th ed., Saunders, Philadelphia, ro68, pp. ro5-286.

223 D. D. Fedfrman, J. Robbins AND J. E. Rall, J. Clin. Invest, 37 (1958) roz4.

224 S. H. Ingbar, $A$ nn. N.Y. Acad. Sci, 86 (r960) 440.

225 S. H. INGBAR, J. Clin. Invest., 42 ( $\left.\mathrm{rg}_{3}\right) \mathrm{I}_{43}$.

226 S. F. B. Heidjemann and G. A. Lnndeboom, Clim. Chim. Acta. 3 (I958) 565 .

227 R. J. VIVacoua, F. I. HAurani ANd A. J. ERslev, Amn. Imternal Med., 67 (1967) 380.

228 M. T. Harrison, R. MCG. Harden and W. D. Alexander, Melabolism, 6 (T967) 84 .

229 S. Reichir, M. G. Koussa and F. W. WItT, J. Clin. Endocrinot. Metab., r9 (1959) 692.

230 R. H. Williams and J. L. BaKKe, in R. H. Wrlliams (Ed.), Textbook of Endocrinology, 3 rd ed., Saunders, Philadelphia, 1962, pp. 96-275.

23 I J. M. Hershman, T. J. Crane AND J. A. Colwell, f. Cinin. Endocrinol. Metab., 28 (1968) 1605.

232 L. S. Craig, R. E. Ray, S. H. Waxler and H. Madigan, Amer. J. Clim. Nuty., iz (rg63) 230.

233 Y.-H. Chang, R. Pinson, JR. And M. H. Malone, Biochem. Phamacol, r6 (r967) 2053.

234 J. M. HANSEN, Acla Endocrinol., 60 (1969) 294.

235 M. T. Harrison and R. McG. Harden, Scot. Med. J., I I (Ig66) 2 I 3.

236 J. S. Marshall and L. S. Tompkins, J. Clin. Endocrinol. Metab., 28 (I968) 386.

237 E. L. Mazzaferri and T. G. Skillman, Amer. J. Med. Sei., 257 (rg69) 388.

238 I. YAMADA, J. Whallon, I. TOMIZAWA, S.-I. SHIMODA AND K. SHICHIJo, Metabolism, 4 (I965) $28 \mathrm{I}$.

239 T. S. Danowski, G. Sabeh, J. W. Vester, M. E. Sarver and J. H. Sunder, Arch. Internal Med., II5 (rg65) 294.

$240 \mathrm{C}$. Robbins, Arizona Med., I4(1957) 3 .

$24 \mathrm{I}$ F. W. SUnderman, JR., in F. W. SUNDERMaN AND F. W. SUNdERMaN, JR. (Eds.), Evaluation of Thyroid and Payathyroid Functions, Lippincott, Philadelphia, 1963, pp. 53-76.

242 J. Wolfe, M. E. Standaert and J. E. Rall, J. Clin. Invest, 40 (I96r) I373.

243 J. H. Oppenteimer AND R. R. Ravernett, Endocrinology, 7 I (I962) 496.

244 J. H. Oppenheimer, G. Bernstein and J. Hasen, J. Clin. Invest, 46 (1967) 762.

245 W. ChIN AND G. C. SCucrsser, $J$, Clin. Endocrinol. Metab., 28 (1968) I8r.

$246 \mathrm{~S}$. Slater and M. Numeroff, Negk Enot. J. Mod, 264 (ro6r) 449.

247 J. T. Dowling, N. Frernkel and S. H. IngBar, J. Clin. Endocyinol. Metab., r6 (r956) r491.

248 W. Fore, P. Kohler Awd J. Wyns, J. Clin. Endocrinol. Metab., 26 (I966) 82 I.

249 N. C. Leone, E. C. Leatelerwood, I. M. Petrie and L. Lieberman, J. Amer. Dental Assoc., $69(1964) \times 79$. 
250 K. A. WoEBER AND S. H. INGBAR, J. Clin. Invest., 43 (I964) 93 r.

25 I A. B. Fisher, R. P. Levy and W. Price, New Engl. J. Med., 273 (1965) 8 I2.

252 H. MEHBOD, C. D. SwAETz AND A. N. BREST, Arch. Intewnal Med, rtg (rg67) 283.

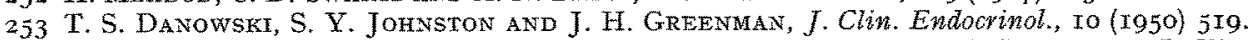

254 T. S. Danowski, F. Mateer, F. A. Wetgand, J. H. Peters and J. II. Greenman, J. Clin. Endocrinol., xo (1950) 532 .

255 T. S. Danowski and J. II Grennman, Trans. Amer. Goiter Assoc, (1949) I 54.

256 G. Freund, W. C. Thomas, JR., E. D. Bird, R. N. Krnman and A. P. Black, J. Clin. Endocrinol. Metab., 26 (I966) 6 r9.

257 D. G. FrIEND, New Engl. J. Med., 263 (T96r) 1358.

258 S. Slater ANd M. Numeroff, New Engh. $J$. Med., 259 (r958) 974.

259 P. H. Sonksex, R. P. EnkINs, H. G. Stevens, E. S. Willtams ANd J. D. N. Nabarro, Lancet, ii $(1968) 425$.

260 R. L. Vought, W. T. London AND F. A. Brown, J. Ctin. Endocrinol. Metab., $24(1964) 414$. 26 I P. K. BONDY, J. Clin. Endocrinol., I I (195 I) I 406.

262 B. Zak, H. H. Willard, G. B. Myers AND A. J. Boyle, Anal. Chem., 24 (1952) 1345.

263 L. Szántó And A. L. Reviczkx, Acta Physiol. Acad. Sci. Hung., 30 (rg66) 233.

264 M. Stennberg And H. C. Leifaert, Texas Rep. Biol. Med., 23 (ro65) 122.

265 R. McG. Harden, C. J. S. Chisholm aNd J. S. CaNt, Metabolism, I6 (I967) 890.

266 M. I. Strks aND J. H. OppendeIMER, Endoorinology, $72(1963) 567$.

267 J. E. Oltman and S. Frtedman, $J$. Amer. Med. Assoc., i85 (1963) 726.

268 J. M. HaNsen AND K. Srersboek-NielseN, Acta Endocrinot, $5.5(1967)$ 1 36 .

269 I. R. King and A. W. Drdole, Amer. J. Obstet. Gynecol., ro8 (1970) I I 75.

270 G. De Srmoni, Minerva Med., 48 (I957) 404.

27 I R. J. Henry, Clinical Chemistry: Principles and Technics, Hoeber, New York, I964, p. 943.

272 J. J. Canary, M. Schaf,, B. J. Duffy, Jr. ANd L. H. KYle, New Engl. J. Med., 257 (I957) 435.

273 B. F. Good, H. A. Potter ANo B. S. Hetzel, Australian J. Exp. Biol. Med. Sei, 43 (ro65) 29 r.

274 B. S. Hetzel, J. S. Charnock AND H. LANDER, Metabolism, 8 (r959) 205.

275 B. S. Fetzel, B. F. Good, M. L. Weilby AND J. S. Charnock, Lancet, i (ig60) 957.

276 B. F. Good, B. S. Hetzel AND L. J. OpIt, J. Endocrinol, 2 I (I960) 23 I.

277 F. K. Austen, M. E. Rubint, W. H. Meronex and J. Wolff, J. Clin. Invest., 37 (I958) II3I.

278 B. U. Musa, R. S. Kumar and J. T. Dowling, J. Clin. Enodorinol. Metab., 28 (1968) I46I.

279 V. J. Pileggi, H. A. Segal and G. F. Lanchanin, Clin. Chim. Acta, 8 (I963) 547.

280 K. L. Becter, S. Katz and A. Mrale, Jr, J. Amer. Med. Assor., 199 (I967) 4 I6.

28 r S. S. Bora, I. Radichevich AND S. C. Werner, J. Clin. Endocrinol. Metab., 29 (1969) r269.

282 C. J. Andersen, N. R. Keiding And A. B. Nielsen, Soand. J. Clin. Lab. Invest, r6 (ro64) 249 .

283 A. W. Wase, E. Repplinger and W. C. Foster, Endocrinology, 53 (r953) 630.

284 H.-D. Taubert, A. L. H.askins and E. F. Moszkowski, Southern Med. J., 59 (r966) r 30 .

285 G. HANNo aND H. K. AWWaD, J. Endocrinol, 25 (1962) 343.

286 R. D. Simbari and E. Houghton. Arch. Internal Med., 123 (1969) 597.

287 L. E. Braverman and A. E. Foster, J. Nucl. Med., ro (1969) 5 r.t.

288 M. A. Quaree axd J. J. Matoole, Ame*. $J$. Chn. Pathol., 48 (rg67) 87.

289 V. J. Prleggi, N. D. LEe, O. J. Golub and R. J. Ienry, J. Clin. Endocinol. Metab., 21 (I961) I272.

290 V. J. Puefgat and G. Kessler, Clin. Chem., x4 (I968) 339.

29 I B. E. P. Murphy and C. J. PATtee, J. Clin. Endocrinol. Metab., 24 (I964) I 87.

292 B. E. P. MuRPHy, Recent Progr. Hommone Res., 25 (I969) 563.

293 J. C. Sisson, J. Nucl. Med., 6 (r965) 853.

294 P. Cusmman, JR., S. Alter and J, G. Hilton, Acta Endocrinol., 50 (1965) 329.

295 M. W. Hamolsky, A. Golodetz and A. S. Fremoberg, J. Clin. Endocrinol. Meiab., 19 (1959) IOS.

296 R. P. Levy and J. S. Marshall, Aroh. Internal Med., II 4 (1964) $4 \mathrm{~T} 3$.

297 D. L. Schatz, R. H. Sheppard, G. Steiner, C. S. Chandarlapaty and G. A. de Veber, $J$. Clin. Endocrinol. Metab., 29 (I969) IoI 5.

298 F. C. Cristofori and G. G. Duncan, New Engl. J. Med., 27 r (1964) 564.

299 H. T. HADEN, Postgrad. Med., 4o (r966) I 29.

300 M. F. Magalotix, I. F. Hummon and E. Hrerschbiel, Amev. J. Roentgenol., 8I (1959) 47.

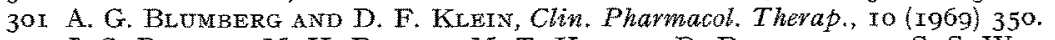

302 J. S. Dtmlao, M. H. Brootes, M. T. Krauss, D. Bronsky and S. S. Waldstern, J. Gin. Endocrinot. Metab., 30 (1970) 53 r.

303 D. A. Frsher, T. H. ODDie AND D. Epperson, J. Clin. Endocrinot. Metab., 25 (r965) I580.

304 B. A. Sachs, E. Sieger, B. N. HorwitT AND E. Siegel, Brit. Mad. J., i (1972) 79 . 
305 S. N. Sptes, Proc. Soc. Exp. Biol. MIed., 86 (r954) 469.

306 E. H. CRanswick ANd G. M. Simpson, Amer. J. Psychiat, 120 (ro64) r133.

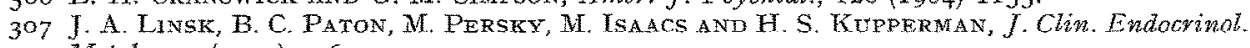
Metab. $17(\mathrm{xg} 7) 4 \mathrm{r} 6$.

308 W. D. Alexander And K. W. M. Johnson, Clin. Sci., I7 (1958) 377 .

309 J. Logan, New Zealand Med. J., 56 (1957) 249.

3io S. Morgenstern, M. Oklander, J. AUerbach, J. Kautman and B. Kitern, Clin. Chem., Iz (I966) 95 .

3i I P. L. Wole, C. Langston, A. I. Potolsky and D. J. Willrams, Clin. Chem., i7 (197x) $34 \mathrm{~T}$.

3I2 K. YoUnG, S. C. STEWART AND S. WeITz, Cliw. Chem., i5 (I969) 776.

3I3 J. J. MoORE AND S. M. SAX, Clin. Chem, 15 (Ig69) 730 .

314 L. D. Sabath, D. A. Gerstetin ANd M. Fincand, New Engl. J. Med., 279 (rg68) Ir 37.

$3^{1} 5 \mathrm{~J}$. W. KEYSER AND C. C. ENTWistle, Lancet, i (Ig67) III.

3 I6 S. B. KorrTz AND P. P. Coken, J. Biot. Chem., 209 (I954) I 45.

3 I 7 H. L. Rosenthal, Anal. Chem., 27 (I955) I980.

3 I 8 J. T. Wha RNE, Anal. Chem, 35 (I963) 327 .

319 P. Fleury and R. Eberhard, Ann. Pham. France, I6 (1958) 465.

320 R. J. Henry and N. Chiamort, Amer. J. Clin. Pathol., 29 (1958) 277.

32 I H. Wrec, Amer. J. Med. Technol., 26 (ro60) xtr.

322 T. K. With, T. D. Petersen and B. Ptetersen, J. Clin. Painot, I4 (T96i) 202.

323 N. LAMBOOY AND G. VAN AMson, Lancet, in (r966) I $36 \mathrm{r}$.

324 C. G. NiLsson, Lancet, i (x967) I65.

325 M. Batlly, P. Fonty and N. LEGER, Ann. Biol. Clin. (Pavis), 25 (I967) I $22 \mathbf{I}$.

326 R. G. Martinek, J. Amer. Med. Technol., 32 (1970) 233.

327 L. Lidder, J. E. SeEgmil. er and L. LASTER, J. Lab. Clin. Med., 54 (1959) 903.

328 W. T. CARAWAY, Clin. Cham., T5 (1969) 720 .

329 O. H. Buchanan, W. D. Block AND A. A. Christman, J. Biol. Chem, I57 (1945) I8I.

$33^{\circ}$ O. H. Buchanan, A. A. Chrtstman aND W. D. Block, J. Biol. Chem, I5T (1945) 189.

$33 \mathrm{I}$ W. T. CARAWAY, Clin. Chem., 4 (1958) 5 I3.

332 M. J. CAWEIN AND J. HEWTNS, New Engl. J. Med., 28 r (I969) I 489.

333 T. F. YÜ AND A. B. Gutman, J. Clin. Invest., 38 (1959) 1298.

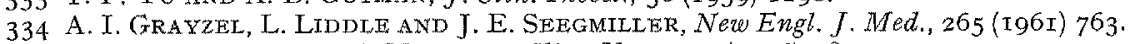

335 W. T. CARAwaY AND H. Marable, Clin. Chem., r2 (1966) i 8.

336 B. Baltrov, in D. Seligson (Ed.), Standard Methods of Clinical Chemistry, Vol. 2 , Academic Press, New York, 1958, pp. I92-305.

337 C. J. Watson, L. Taddemin ANd I. Bossenmater, J. Ame\%. Med. Assoc.. I9o (Ig64) 50 .

338 J. D. Bauer, P. G. Ackermans and G. Toro, Bway's Chimal Laboratory Methods, Mosby, St. Louis, 7 th ed., rg68, p. 37 .

339 T. BaUMGaRTEL, Klin. Wochschr., 26 (I948) 22.

$34^{\circ}$ S. A. Levinson and R. P. MacFate, Clinical Laboratory Diagnosis, 7 th ed., Lea \& Febiger, Philadelphia, I969, p, 647 .

34 I J. B. JEPson, in I. SMIIH (Ed.), Chromatographic and Electrophoretic Techniques, Vol. 1 , 3 rd ed., Interscience, New York, r969, pp. 243-273.

342 E. W. KonmMan AND J. SChessler, Ame\%, J. Clin. Pathol, $44(1965) 358$.

343 K. N. T. SHAW aNo J. TREVARThEN, Natize, r8z (1958) 664.

344 S. E. Gitlow, L. Ornstein, M. Mendlowitz, S. Khassis and E. Kruk, Amer. J. Med., 28 (1960) $92 \mathrm{r}$.

345 D. J. Mahler and F. L. Humolier, Clin. Chem, 8 (I962) 47.

346 A. AMERy and J. Conway, Amer. Heart J., 73 (Ig67) I 29.

347 D. J. Campbell, R. Sherbaniuk and J. Rigby, Cim. Chem., ro (1964) 447.

348 M. Fimsher, M. R. Dollinger. And M. K. Schwartz, Amer. J. Cim. Pathol., 5 I (1969) 555.

349 J. J. Pisano, J. R. Crout and D. Arragam, Clin. Chim. Acta, 7 (1962) 285 .

350 M. H. SACRE AND G. WAIKER, Cim. Chim. Acta, 30 (ro7o) 215 .

$35 \mathrm{I}$ G. M. Txce, S. G. Sheps AND E. V. Fuock, Proc. Staff Metings Mayo Clinic, 38 (1963) $57 \mathrm{~T}$.

352 G. H. ELDER, Clin. Chim. Acta, rg (I968) 507 .

353 M. Greten A.ND G. Walker, Clim. Chim. Acta, 29 (1970) I89. 